\title{
No evidence for tephra in Greenland from the historic eruption of Vesuvius in 79 CE: Implications for geochronology and paleoclimatology
}

Gill Plunkett ${ }^{1}$, Michael Sigl ${ }^{2}$, Hans Schwaiger ${ }^{3}$, Emma Tomlinson ${ }^{4}$, Matthew Toohey ${ }^{5}$, Joseph R. 5 McConnell $^{6}$, Jonathan R. Pilcher ${ }^{1}$, Takeshi Hasegawa ${ }^{7}$ and Claus Siebe ${ }^{8}$

${ }^{1}$ Archaeology \& Palaeoecology, School of Natural and Built Environment, Queen's University Belfast, Belfast BT7 1NN, UK

${ }^{2}$ Climate and Environmental Physics and Oeschger Centre for Climate Change Research, University of Bern, 3012 Bern, Switzerland

${ }^{3}$ Alaska Volcano Observatory, U.S. Geological Survey, 4230 University Drive, Suite 100, Anchorage, AK, 99508, USA

$10 \quad{ }^{4}$ Department of Geology, Trinity College Dublin, Dublin, Ireland

${ }^{5}$ Institute of Space and Atmospheric Studies, University of Saskatchewan, Saskatoon, Canada

${ }^{6}$ Desert Research Institute, Nevada System of Higher Education, Reno, Nevada 89512, USA

${ }^{7}$ Department of Earth Sciences, College of Science, Ibaraki University, 2-1-1 Bunkyo, Mito 310-8512, Japan

${ }^{8}$ Department of Volcanology, Institute of Geophysics, National Autonomous University of Mexico, C.P. 04510, Coyoacán,

15 Mexico

Correspondence to: Gill Plunkett (g.plunkett@qub.ac.uk)

\begin{abstract}
Volcanic signatures archived in polar ice sheets provide important opportunities to date and correlate ice-core records as well as to investigate the environmental impacts of eruptions. Only the geochemical characterization of volcanic ash (tephra) embedded in the ice strata can confirm the source of the eruption, however, and is a requisite if historical eruption ages are to be used as valid chronological checks on annual ice layer counting. Here we report the investigation of ash particles in a Greenland ice core that are associated with a volcanic sulfuric acid layer previously attributed to the 79 CE eruption of Vesuvius. Major and trace element composition of the particles indicates that the tephra does not derive from Vesuvius but most likely originates from an unidentified eruption in the Aleutian arc. Using ash dispersal modelling, we find that only an eruption large enough to include stratospheric injection is likely to account for the sizeable (24-85 $\mu \mathrm{m})$ ash particles observed

25 in the Greenland ice at this time. Despite its likely explosivity, this event does not appear to have triggered significant climate perturbations, unlike some other large extra-tropical eruptions. In light of a recent re-evaluation of the Greenland ice-core chronologies, our findings further challenge the previous dating of this volcanic event to $79 \mathrm{CE}$. We highlight the need for the revised Common Era ice-core chronology to be formally accepted by the wider ice-core and climate modelling communities in order to ensure robust age linkages to precisely dated historical and paleoclimate proxy records.
\end{abstract}


https://doi.org/10.5194/cp-2021-63

Preprint. Discussion started: 16 June 2021

(c) Author(s) 2021. CC BY 4.0 License.

\section{(c) (i)}

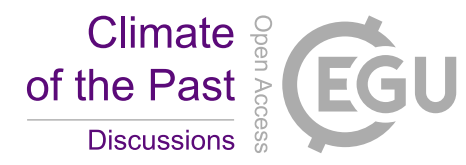

\section{Introduction}

Volcanism is now widely accepted as the most significant natural driver of high frequency (i.e., inter-annual to centennial timescales) climate variability (Schurer et al., 2013; Crowley, 2000). Polar ice cores provide long, continuous records of potentially climatically effective volcanism through their capture of volcanic aerosols, halogens and particles (Hammer et al., 1980; Zielinski et al., 1994). The precise dating of the volcanic signals proffered by the ice cores enables the climate and societal impacts of volcanic eruptions to be evaluated with respect to historical records, and has contributed to the discernment of strong chronological correlations between past volcanism, climate perturbations and societal upheaval (Sigl et al., 2015; Büntgen et al., 2016; Toohey et al., 2016).

40 Volcanic sulfate (or sulfur) remains the primary proxy in the ice cores used for reconstructing past volcanism, as continuous records can be obtained through semi-automated continuous flow processes along the entire length of an ice core (McConnell et al., 2002, 2017). Volcanic sulfates cannot, however, pinpoint the source of the eruption, a critical factor needed to determine the amount of the aerosol emissions and their lifetime, and thus climatic effectiveness of an eruption. In particular, stratospheric injection height of material is key to controlling the radiative forcing potential of an eruption. In the absence of documented evidence, eruption column height can be estimated from grain size analysis of proximal tephra fallout (Carey and Sparks, 1986; Burden et al., 2011). Volcanic ash (fine-grained tephra, often referred to as cryptotephra when shard concentrations are too low to be visible to the naked eye) in ice cores can also enable the source volcano to be identified, thus improving the scope for modelling aerosol distribution and climate impact. The geochemical composition of tephra is a product of the magma composition from which it derives, which is determined by the local geology. As the magma source is subject to changes in

50 supply, temperature and pressure, tephra chemistry may be unique to each eruption, or phase of the eruption, but frequently carries a geochemical signature in its major or trace element composition that enables it to be attributed to a specific source.

Here we examine a tephra associated with a large volcanic sulfate signal in Greenland ice previously attributed to the $79 \mathrm{CE}$ eruption of Vesuvius (Fig. 1; Hammer et al., 2003; Vinther et al., 2006; Barbante et al., 2013). The event has no coinciding

55 Antarctic signal, which would support the theory of a Northern Hemisphere extratropical source. The sulfate signal in Greenland is rather strong: the global radiative forcing from the eruption was estimated to rank $23^{\text {rd }}$ of all eruptions of the past 2500 years (Sigl et al., 2015). Under the assumption of an extratropical source, the stratospheric sulfur injection of the eruption is estimated to be $10.6 \mathrm{TgS}$ (Toohey and Sigl, 2017), which would be the $5^{\text {th }}$ largest injection from an extratropical NH eruption over the same time span, comparable to the upper range of estimates for the 1912 Katmai eruption (Stothers, 1996) and greater

60 in sulfur injection than the 1991 Mt. Pinatubo eruption. The attribution of the event to Vesuvius was initially based upon the acid layer's apparent temporal coincidence with the 79 CE eruption (Zielinski, 1995) and later appeared to be confirmed by the analysis of diminutive tephra particles ( $2-5 \mu \mathrm{m}$ particle size) in the GRIP ice core whose geochemistry was found to be consistent with Vesuvius tephra (Barbante et al., 2013). 
65 The Greenland Ice Core Chronology 2005 (GICC05) provides a synchronized dating for three Greenland ice cores (NGRIP, GRIP and Dye-3) in which three volcanic marker events were believed to correspond to historic volcanic eruptions (i.e., Vesuvius 79 CE, Hekla 1104 CE and Öraefajökull 1362 CE). These horizons were subsequently assigned an age uncertainty of \pm 0 years (Vinther et al., 2006), though only for the last-mentioned was the matching supported by a strong geochemical correlation of tephra (Coulter et al., 2012). This ice-core chronology has since been revised, however, following the recognition of distinct solar proton events at 774 and 993 CE that highlighted a temporal offset in the Greenland Ice Core Chronology 2005 (GICC05), prompting the construction of revised ice-core chronologies, NS1-2011 (Sigl et al., 2015) and DRI_NGRIP2 (McConnell et al., 2018). As a result, the date of the sulfate layer formerly assigned to Vesuvius 79 CE is now placed at 88 CE, with a smaller volcanic sulfate concentration peak at 80 CE in NGRIP2 and GISP2 (Fig. 1b). We identify in the northern Greenland NEEM-2011-S1 ice core an unambiguous tephra associated with the $88 \mathrm{CE}$ event. We consider the potential source

75 of the tephra and examine the consequences of attributing ice core volcanic signals to specific events in the absence of supporting evidence.

\section{Methods}

Three ice samples bracketing a sulfate peak at $410.56 \mathrm{~m}$ in the NEEM-2011-S1 core were cut for tephra analysis between $80410.20-410.85 \mathrm{~m}$ using a bandsaw in the ice core laboratory at the Desert Research Institute (DRI), Nevada (Fig. 1c). Samples were transferred to precleaned Nalgene bottles and sent to Queen's University Belfast (QUB) for tephra extraction where they were assigned unique identifier codes (QUB-1832: 410.85-410.65 m; QUB-1833: 410.65-410.40 m; QUB-1834: 410.40$410.20 \mathrm{~m}$ ). The meltwater was centrifuged to concentrate particulates, which were then pipetted onto pre-ground glass slides on a hotplate in a laminar flow cupboard. The samples were covered in Buehler epoxy resin. Tephra shard content was

85 quantified using $\times 100-400$ magnification on a light microscope with the aid of cross polarization. Samples containing tephra were ground using $12 \mu \mathrm{m}$ alumina powder and polished using $6 \mu \mathrm{m}, 3 \mu \mathrm{m}$ and $1 \mu \mathrm{m}$ diamond paste until the surfaces of the shards were exposed for analysis.

To determine the source of the tephra, major element geochemical analysis was performed on a JEOL FEGSEM 6500F at 90 QUB and trace element composition was analyzed by Laser Ablation Inductively Coupled Plasma Mass Spectrometry (LAICP-MS) on a Thermo SCIENTIFIC iCAP Q coupled to a Photon Machines Analyte Excite Excimer UV laser at the iCRAG Lab at Trinity College Dublin. Methods and operating conditions are presented in Dataset 1 in the Supplement. Major element compositions have been normalized to $100 \%$ to enable comparison with published material (raw and normalized data are presented in Dataset 1 in the Supplement). 
To evaluate possible source eruptions for the recorded tephra, a list of all known eruptions within the period 100 BCE-300 CE with an estimated Volcanic Explosivity Index (VEI) of $\geq 4$ was collated from Siebert et al. (2011), supplemented by data from the Smithsonian's Global Volcanism Program (GVP; http://volcano.si.edu/; Dataset 2 in the Supplement). The wide timespan allows for chronological uncertainty of the events, none of which is historically dated with the exception of Vesuvius 79 CE. In view of Iceland's vicinity to Greenland, we also considered smaller magnitude eruptions from this region, excluding those volcanic systems that typically produce homogenous basaltic glasses, such as Grímsvötn and Bárdarbunga. Where possible, reference glass geochemical data for the events were collated from published records for comparison with the tephra identified in the NEEM-2011-S1 ice core, and were added to the QUB tephra database. For possible correlatives, we analyzed reference glass samples for geochemical analysis under the same operating conditions as the NEEM-2011-S1 tephra (see Supplementary Information in the Supplement for sample details).

On the basis of three potential source volcanoes suggested by the tephra geochemistry (namely Aniakchak, Chikurachki, and Popocatepétl; see Fig. 1), we modelled ash distribution using the advection-dispersion-sedimentation software Ash3d (Schwaiger et al., 2012) to evaluate the necessary eruption and meteorological parameters needed to transport ash as far as the

110 NEEM coring site $\left(77^{\circ} 27^{\prime} \mathrm{N} 51^{\circ} 3.6^{\prime} \mathrm{W} ; 2,000 \mathrm{~m}\right.$ above sea level). Ash3d calculates tephra deposition as mass per unit area at sites, even if the fallout is vanishingly small. Hence, even exceedingly small fallout values contributing very low concentrations of tephra can be identified as non-zero values (Dunbar et al., 2017). Model parameters were selected on the basis of each volcanic source under consideration (see Sect. 3.4). As the meteorological conditions at the time of the eruption are not known, we used data drawn from the 2.5 degree NCEP-NCAR Reanalysis II dataset (https://climatedataguide.ucar.edu/climate-

115 data/ncep-reanalysis-r2) that captures 3D time-varying atmospheric structure (including temperature and horizontal and vertical winds). Start dates and times for the events were selected randomly from the period between 1950 to 2010, but limited to just the winter months (November-February), reflecting the likely season of the eruption based on sulfate and tephra deposition in the ice core (Sigl et al., 2015; McConnell et al., 2018). For each of the three sources, 350 simulations were run. Additionally, to distinguish meteorological differences from differences in the eruption source parameters, we randomly

120 selected 1,000 start times from 1950 to 2010, and simulated events using identical source parameters at the three locations of interest.

\section{Results}

\subsection{The NEEM-2011-S1 tephra}

Cryptotephra was identified in samples QUB-1832 $(n=18)$ and QUB-1833 $(n=5)$, demonstrating that ash deposition preceded

125 the maximum of sulfuric aerosol depositions at this location in Greenland. Shards were pale brown, ranged between 24 and 85 $\mu \mathrm{m}$ in longest axis, and displayed a varied morphology, including blocky, bubble-wall and platy shards, some with elongated or occasionally spherical vesicles (Supplementary Information in the Supplement). Several shards contained minerals, and one 
was microlite-rich. Major element analyses of the glass were obtained for six and three shards in these samples, respectively, and trace element data for five and three of the shards. The data reveal a homogenous, andesitic glass that evidently derives from a single source and the sample is hereafter named QUB-1832/3. Major and trace element compositions suggest a source along an active arc (cf. Tomlinson et al., 2015; Fig. 2).

The GVP database lists five VEI 6, three VEI 5 and 31 VEI 4 eruptions dating to between 100 BCE and 300 CE. The VEI 6 eruptions include that of Churchill, Okmok and Ksudach, whose chronologies have all been recently revised and no longer encompass the first century CE (Ponomareva et al., 2017; McConnell et al., 2020; Reuther et al., 2020). The magnitude of Ambrym, Vanuatu - previously thought to have entailed a cataclysmic collapse of the caldera - has also been questioned and was likely a less pronounced, gradual event (Németh et al., 2009). Of the three VEI 5 eruptions, only Masaya is located on an active arc. We have been unable to find major element glass geochemistry for many of the VEI 4 eruptions, but we draw upon trace element data (for glass or whole rock), tectonic setting and information from other eruptives to evaluate their correspondence with QUB-1832/3 (Dataset 2 in the Supplement).

\subsection{Major element geochemistry}

The QUB-1832/3 glass geochemistry is clearly distinct from Vesuvius glass and from the data presented for the GRIP ash particles by Barbante et al. (2013). On the basis of major element compositions, we can also firmly reject correlations with the VEI 6 eruptions from Ksudach, Okmok, Churchill (WRAn tephra), Apoyeque (Chiltepe tephra) and Taupo, and the VEI 5 eruptions from Furnas and Masaya (Fig. 3a, b). We lack a full suite of data for Ambrym, but glasses from this eruption do not include an andesitic component (Robin et al., 1993). We find no geochemical matches with any of the VEI 4 eruptions for which we have data. We also exclude Iceland as a source, as the geochemistry matches neither the known eruptions of this time period nor any other Icelandic tephras for which we have data. Similarly, we discount Jan Mayen from consideration as only basaltic tephras have been reported from this source (Gjerløw et al., 2016), and no eruption is known in the timeframe under consideration. The geochemistry does not correlate with any known Kamchatkan source (Kyle et al., 2011; Ponomareva et al., 2017; V. Ponomareva, pers. comm.).

Extending our search beyond the age range of the QUB-1832/3 tephra, we find geochemical correlations with two shards (Shards \#5 and \#7) within the mixed population of QUB-1859 from NEEM-2011-S1, dated to 536 CE (NS1-2011 chronology;

155 Sigl et al., 2015; Fig. 4). A comparison with published data reveals a close similarity to the andesitic component of Aniakchak (Kaufman et al., 2012; Davies et al., 2016) and to material from Mount Spurr (Riehle, 1985; Béget et al., 1994; Child et al., 1998). QUB-1832/3 has a slightly lower $\mathrm{TiO}_{2}$ content than the Aniakchak tephra, however. Although no large Aniakchak eruptions are known from the timeframe of interest, the GVP reports an eruption with no assigned VEI at 255 \pm 200 CE. Point data are not available for the Mount Spurr tephras but the average $\mathrm{FeO}_{\text {total }}$ content also tends to be lower than the NEEM-2011S1 tephra (Fig. 5). No activity at this volcano has been reported in the timeframe of the $88 \mathrm{CE}$ event. 
Other close major element correlations include OSC1-5 (a series of five eruptions dating to between $1650 \mathrm{BCE}$ and $400 \mathrm{CE}$ ) from Chikurachki, Kurile Islands (Hasegawa et al., 2011), and matrix glasses from Popocatépetl, Mexico (Siebe et al., 1996). The Chikurachki eruptions are not listed in the GVP database, but large Popocatépetl eruptions are dated to 200 \pm 300 BCE

165 (VEI 5: Lorenzo Pumice) and 822-823 CE (VEI 4: Pink Pumice), the latter date based on an assumed linkage with a sulfate peak in the Greenland ice core GISP2 (Siebe et al., 1996, 2017) at this time (817 CE on the NS-2011 timescale). We reanalyzed OSC1-5 glass and reference samples from Popocatépetl, including material from the Lorenzo and Pink Pumices, and from reference ash samples provided by the Smithsonian Institution, on the JEOL FEGSEM 6500F (Fig. 4). Our results show that QUB-1832/3 differentiates from OSC1-5 in $\mathrm{FeO}_{\text {total }}$ and $\mathrm{CaO}$ content, rendering Chikurachki an unlikely source of the

170 NEEM-2011-S1 tephra. Analyses from the Pink and Lorenzo Pumices from Popocatépetl demonstrate homogenous dacitic to rhyodacitic glass compositions, that do not overlap with the andesitic datapoints of QUB-1832/3. The Smithsonian samples from an unspecified event or events - show greater compositional variability along a trend from rhyolitic to basaltic trachyandesitic. The majority of analyses obtained from these samples have a rhyolitic to dacitic composition, seemingly on a compositional trend towards the QUB-1832/3 population except in $\mathrm{FeO}_{\text {total }}$ concentrations. Some rhyolitic shards of QUB-

1751859 (Shards \#1, \#10, \#11 and \#2: Sigl et al., 2015) attributed to the 536 CE fallout closely match the high-silica Popocatépetl analyses, but divergence in $\mathrm{TiO}_{2}$ (Shards \#1, \#10, \#11) or $\mathrm{K}_{2} \mathrm{O}$ (Shard \#2) is evident.

\subsection{Trace element geochemistry}

The trace element signature of QUB-1832/3 is clearly distinct from candidate eruptions in Latin America (Fig. 5a-c). Lesser Antilles sources have a Rb-U and $\mathrm{Ta}>\mathrm{Na}$ signature that distinguishes them from the cryptotephra. Although less evolved than

180 the Japanese tephras reported by Albert et al. (2019), the trace element composition of the QUB-1832/3 glass is inconsistent with Japanese sources (Fig. 5d).

Our best matches using major element geochemistry are with two andesitic shards in QUB-1859, various Holocene andesitic eruptives of Aniakchak and two recent eruptives from Mount Spurr; our analysis of Popocatépetl is inconclusive. Trace element

185 data were collected from the pertinent shards in QUB-1859 and confirm that these shards derive from the same source as QUB1832/3 (Fig. 6). Attempts to analyze other shards within QUB-1859, specifically those lying close to the rhyolitic end of Popocatépetl compositional field, were unsuccessful due to the entrapment of minerals.

We compared our results with published trace element data for Aniakchak glass (Kaufman et al., 2012) and with newly obtained data from the four Smithsonian reference samples from Popocatépetl. Our analyses show that the ice-core tephras are lower in trace element concentrations than Aniakchak but share consistent high field strength element (HFSE) ratios, and a link with this source or source region cannot be excluded (Fig. 6b-d). In contrast, clearly distinctive HFSE ratios (e.g., Th: Nb; 
https://doi.org/10.5194/cp-2021-63

Preprint. Discussion started: 16 June 2021

(c) Author(s) 2021. CC BY 4.0 License.

\section{(c) (i)}

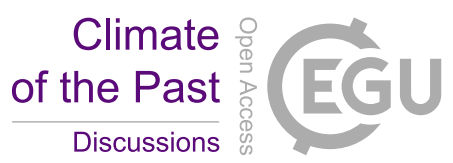

Fig. 6d) differentiate the tephra from Popocatépetl and allow this source to be eliminated. We were unable to locate trace element data for Mount Spurr.

\subsection{Modelling ash dispersal}

Our geochemical analysis of the QUB-1832/3 tephra demonstrates that it derives from an eruption other than a known event of VEI 4 or higher listed in the GVP database. The geochemical composition also enables us to eliminate from consideration well-characterized volcanoes in Iceland, Kamchatka and, on the basis of trace element composition, the Lesser Antilles and Japan. Other likely source regions include Alaska, the Kuriles arc and Mexico. We therefore explore the eruption parameters needed for tephra to be transported from these sources to Greenland, by modelling ash dispersal from the three candidates (Aniakchak, Chikurachki and Popocatépetl) highlighted by major element geochemical similarities.

Despite a lack of clear correspondence in the major and trace element composition, we cannot firmly reject Aniakchak or a neighboring system as a possible source of the QUB-1832/3 tephra. Aniakchak is not known to have erupted in the timeframe of interest, implying that any such eruption is unlikely to have been very large, or deposits would have been preserved locally. Since the caldera-forming eruption (CFE) at 1640 BCE (GICC05 chronology) whose tephra has been securely identified in Greenland ice (Coulter et al., 2012; Plunkett et al., 2017), at least two VEI 4 eruptions have occurred. To simulate ash dispersal, we therefore used parameters for a VEI 4 event erupting $0.5 \mathrm{~km}^{3}$ dense rock equivalent (DRE) volume of tephra with a $12 \mathrm{~km}$ plume height over a duration of 15 hours. In $\sim 10 \%$ of the simulations, fine tephra $(\sim 30 \mu \mathrm{m})$ reached the NEEM ice core drilling site, but not larger particles. The model suggests that a VEI 4 eruption could, under suitable meteorological conditions, disperse ash to Greenland, but probably not a smaller event (Fig. S1 in the Supplement).

Our major element data suggest that Chikurachki is an unlikely source of QUB-1832/3, but large (VEI 4) eruptions from this and other Kurile eruptions are capable of injecting sulfur into the stratosphere, as demonstrated by the 1986 Chikurachki eruption ( $0.75 \mathrm{Tg}$ of $\mathrm{SO}_{2}$ emitted to an elevation of $11 \mathrm{~km}$; Global Volcanism Program, 2013), and the 2019 Raikoke (13-17 $\mathrm{km}$ plume height erupting $1.5 \pm 0.2 \mathrm{Tg} \mathrm{SO}_{2}$; de Leeuw et al. in review). The volcanic history of the Kuriles is poorly constrained prior to the settlement of the region in the 18th century but at least four other VEI 4 eruptions from Chikurachki are known to have occurred during the mid- to late Holocene (Siebert et al., 2011). We therefore examined the potential ash dispersal of a comparable event $\left(0.25 \mathrm{~km}^{2}\right.$ DRE, $11 \mathrm{~km}$-high plume, eruption duration 7 hours, with grain size distribution as described by Belousova and Belousov, 2001) to transport tephra as far as northern Greenland. In none of the Ash3d simulations did tephra reach Greenland (Fig. S2 in the Supplement).

Thirdly, we examine the possible dispersal of Popocatépetl ash. Recent eruptions have here been of a modest nature (VEI 3 or less), injecting small volumes of ash and sulfur into the troposphere. Larger eruptions dating to 200 \pm 300 BCE (VEI 5) and 750 CE (VEI 4) are inferred from tephra fall deposits (known respectively as the Lorenzo and Pink Pumices; Siebe and 
https://doi.org/10.5194/cp-2021-63

Preprint. Discussion started: 16 June 2021

(c) Author(s) 2021. CC BY 4.0 License.

(c) (i)

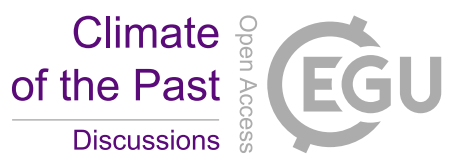

Macías, 2004). For the Ash3d simulations, we used the parameters outlined for an older VEI 6 event, the $~ 3700$ BCE Ochre Pumice (Arana-Salinas et al., 2010): a plume height of $30 \mathrm{~km}$, eruption duration of 20 hours, an eruptive volume of $1 \mathrm{~km}^{3}$ DRE, with a grain size distribution of $250 \mu \mathrm{m}(15 \%), 125 \mu \mathrm{m}(20 \%), 63 \mu \mathrm{m}(40 \%)$ and $31 \mu \mathrm{m}(25 \%)$. In 32\% of the Ash3d simulations, ash reached Greenland, including larger grains $(63 \mu \mathrm{m})$ in eight $(2 \%)$ of the simulations. Ash also dispersed over the Africa, Europe, central Asia and the North American circum-polar region, demonstrating the potential reach of ejecta from large Mexican eruptions (Fig. S3 in the Supplement).

These simulations used eruption source parameters (plume height, eruptive volume, duration, grain-size distribution) that were drawn from past events for Chikurachki and Popocatépetl. To address the question of how big or how small would an eruption need to be or could be for ash from each volcano to fall out in Greenland, we randomly selected 1,000 events and applied the same eruption source parameters to each of the three volcanoes, with eruptions commencing at randomly selected times from a uniform distribution between 1950 and 2010. Eruptive volume was selected from a log-normal distribution between 0.01 and $2.0 \mathrm{~km}^{3}$ (dense rock equivalent). Plume heights were calculated using a best-fit relationship between eruptive volume and plume height with a random adjustment (Gaussian with $\mu=0 \mathrm{~km}$ and $\sigma=2.9 \mathrm{~km}$ ). Mass eruption rate was calculated from a best-fit relationship with plume height and duration using the mass eruption rate and eruptive volume (see Mastin et al., 2020). For all of these 1,000 cases, the same grain-size distribution (GSD) was used (15\% $0.250 \mathrm{~mm}, 20 \% 0.125 \mathrm{~mm}, 40 \% 0.063$ $\mathrm{mm}$, and 25\% $0.031 \mathrm{~mm}$ ). Using a GSD with this greater fine component and considering plume heights in a broader range (7-35 km), hypothetical eruptions at each of the three volcanoes resulted in ash deposited in Greenland. The output of all simulations can be found in Plunkett et al. (2021).

Generally, for both Aniakchak and Chikurachki, the greater the plume height of the hypothetical eruption, the more likely ash will fall out in Greenland (Fig. 8). With Popocatépetl, the trend is not as pronounced. In all cases, no $31 \mu \mathrm{m}$ ash was deposited in Greenland for plume heights less than $9 \mathrm{~km}$ for Aniakchak or $11 \mathrm{~km}$ for Chikurachki and Popocatépetl. In less than $1 \%$ of cases for both Aniakchak and Popocatépetl were $63 \mu \mathrm{m}$ particles deposited and exceptionally large plume heights were required to achieve this (26 and $18 \mathrm{~km}$, respectively). In none of the 1,000 simulations of Chikurachki did $63 \mu \mathrm{m}$ ash reach Greenland.

For these hypothetical cases, $44 \%$ of the simulations of Aniakchak resulted in fine ash deposited in Greenland, as opposed to $25 \%$ and $13 \%$ from Chikurachki and Popocatépetl, respectively. There is a weak sensitivity to season, with a slight increase in the odds of ash reaching Greenland for each of these three volcanoes during wintertime (51\%, 26\%, and 20\% for Aniakchak,

255 Chikurachki and Popocatépetl; Fig. 8d). Again, these likelihoods are only with consideration of the source location with respect to the meteorology. When considering the geologic history, Chikurachki becomes much less likely due to its historically lower plume heights and coarser grains size. 


\section{Discussion}

\subsection{Deconstructing the ice-core "Vesuvius" marker horizon}

260 We identify in the NEEM-2011-S1 ice core a significant concentration of large cryptotephra shards in association with the sulfate layer previously attributed to the Vesuvius $79 \mathrm{CE}$ eruption. Our geochemical characterization of the tephra demonstrates conclusively that it is not derived from Vesuvius. Coupled with the revised NS1-2011 ice core chronology that now places this event in winter 87/88 CE (Sigl et a., 2015), our findings call into question the robustness of the geochemical data from glass shards in the GRIP ice core that were reported by Barbante et al. (2013). In our simulations, ash was deposited almost entirely within days to weeks following the event, although the model is not sufficiently tuned to consider extremely fine particles. We consider it unlikely that Vesuvius ash was being deposited in Greenland up to nine years after the eruption, but the GRIP tephra raises uncertainty about the validity of diminutive $(<5 \mu \mathrm{m})$ ash particles in polar ice cores. Under the revised NS1-2011 and DRI_NGRIP2 chronologies (Sigl et al., 2015; McConnell et al., 2018), a small volcanic sulfate peak in NGRIP2 and GISP2 at $80 \mathrm{CE}$ is observed which may derive from the VEI 5 eruption of Vesuvius in $79 \mathrm{CE}$, or equally an unknown eruption of similar age (Fig. 1b). Drilling of the NEEM-2011-S1 core had been stopped at an age of $86 \mathrm{CE}$ so we could not sample the corresponding depth range for tephra. We suggest that additional screening for potential tephra should be extended by the icecore community to the corresponding core sections of archived ice cores (e.g., NGRIP, NEEM, Dye-3, and others).

Although we have been unable to determine the source of our $88 \mathrm{CE}$ tephra, we rule out on the basis of glass geochemistry the likelihood that it was from Iceland, Greenland's closest volcanic source, or from any known event of VEI 4 or higher presently dated to within $\sim 200$ years of the event, emphasizing that eruption inventories are incomplete and often imprecisely dated (Brown et al., 2014, Rougier et al., 2016). Our ash models suggest that tephra from smaller magnitude eruptions in Mexico or the north Pacific region is unlikely to reach Greenland, and that plumes from the northwestern Pacific must attain elevations of $9 \mathrm{~km}$ or more to have potential to disperse ash as far as the north Atlantic. Stevenson et al. (2015) similarly found that ash from $10 \mathrm{~km}$-high plumes in Iceland could rapidly travel $850 \mathrm{~km}$, but our findings extend the range of moderately high ash clouds to considerably greater distances. For ash particles as large as those in QUB-1832/3 and QUB-1859 to disperse such distances, however much higher (>18 km) plumes are likely needed. The glass geochemistry of the $88 \mathrm{CE}$ tephra most closely resembles products from the eastern Aleutian range, although no candidate eruption can be identified despite the likelihood that it was a large magnitude event. This serves to emphasize the incompleteness of the volcanic record, a salutary reminder that large, unknown eruptions may be candidates for prominent volcanic events in Greenland ice cores even when there are close temporal associations with documented eruptions. 
https://doi.org/10.5194/cp-2021-63

Preprint. Discussion started: 16 June 2021

(c) Author(s) 2021. CC BY 4.0 License.

\section{(c) (i)}

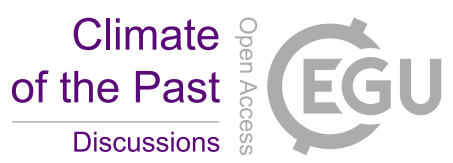

\subsection{Geochronological implications}

The misattribution of the $88 \mathrm{CE}$ signal can be traced back to early ice core research in which Vesuvius was posited as a possible

source because the ice layer counts were within 10 years of the historical eruption (Zielinski, 1995). Subsequent adherence to this unconfirmed tie-point within the Greenland ice-core chronology impeded the recognition of coeval historical and proxy signals of past environmental change despite calls for a reconsideration of the ice-core dating on the basis of similar intervals between events in the ice core and tree-ring records (Baillie, 1996, 2008; Baillie and McAneney, 2015). Nonetheless, the marker event played a pivotal role in the constraining the Common Era section of the GICC05 chronology (Vinther et al., 2006), which is widely considered as the reference chronology for Northern Hemisphere paleoclimate (Rasmussen et al., 2014). All major deep Greenland ice cores are aligned on GICC05 (Rasmussen et al., 2013; Seierstad et al., 2014; Vinther et al., 2006, 2008), including the most recently drilled EGRIP ice-core (Mojtabavi et al., 2020), similar to the way in which Antarctica ice cores are increasingly aligned to the WD2014 chronology (Baggenstos et al., 2018; Buizert et al., 2018; Cole-Dai et al., 2021; Sigl et al., 2016; Winski et al., 2019).

The development of the independent NS1-2011 chronology, unconstrained by this assumed tie-point (and another previously assumed tie-point at $1105 \mathrm{CE}$ ascribed to the Hekla $1104 \mathrm{CE}$ eruption), has since enabled a more precise dating, confirmed by tephra linkages, of past volcanic eruptions (e.g., Ilopango $431 \pm 2$ CE - Smith et al., 2020; Katla 822 CE - Plunkett et al., 2020; Churchill 853 CE - Jensen et al., 2014; Eldgjá 939-40 CE - Oppenheimer et al., 2018; Changbaishan 946 CE - Sun et al., 2014; Veiðivötn 1477 CE -Abbott et al., 2021). The chronology has also enabled a more accurate appraisal of volcanic effects on climate and society, including on Northern Hemisphere summer temperatures (Büntgen et al., 2020; Helama et al.; Zhu et al., 2020), Nile summer flood variability and socioeconomic effects in ancient Egypt (Manning et al., 2017), and Chinese dynastic collapses (Gao et al., submitted). It is largely consistent with an independently annual-layer counted chronology from the NGRIP2 ice core (McConnell et al., 2018, 2019) used to constrain the date and climate effects of the caldera-forming Okmok II eruption in winter 44/43 BCE (McConnell et al., 2020).

Over the last decade, numerous continental- to global-scale temperature reconstructions have been made based on multi-proxy records that include ice cores (McKay and Kaufman, 2014; PAGES 2k Consortium, 2013, 2017, 2019; Neukom et al., 2019; Kaufman et al., 2020; Konecky et al., 2020) and data-assimilation employing these databases (Steiger et al., 2018; Tardif et al., 2019). These reconstructions are increasingly used as a benchmark in assessments of anthropogenic global warming (Steig et al., 2013; Abram et al., 2016; Neukom et al., 2019b) or to explore the role of natural forcing on past climate (Tejedor et al., 2021). In these reconstructions, the relative contribution of ice-core records to the overall proxies is generally increasing with increasing age. In the most recent PAGES2k reconstruction (PAGES 2k Consortium, 2017), 48 ice cores (8\%) are included between 1800-1850 CE, and 22 (24\%) between 500-550 CE. Of the latter 22 records, 10 have been aligned to the GICC05 chronology using volcanic synchronization and only two have been aligned to the new WD2014 chronology (Sigl et al., 2016). 
Because of the reduced fraction of proxies with annual dating precision (i.e., tree-rings) in the first millennium CE and in combination with coarse resolution, dating uncertainties and biases in other proxies, multi-proxy reconstructions consequently depict smaller amplitudes of natural climate variability in the first millennium CE than in the second millennium CE under comparable external climate forcings (Büntgen et al., 2020). Accurate alignment of the available annual resolution data - treerings and polar ice cores - is critical to redress this issue, and hinges on the integration of data based on a robust ice-core chronology. Given our firm refutation of the Vesuvius 79 CE tie-point in the GICC05 chronology, we urge that corresponding databases (e.g., PAGES 2k, PAGES Iso2k, Last Millennium Reanalysis, Paleo Hydrodynamics Data Assimilation) be updated to capture accurately the timing and full amplitude of paleoclimatic variability.

\subsection{Sulfate deposition for $88 \mathrm{CE}$ and implications for climate forcing}

330 Unsupported linkages between volcanic signals and their source have consequences also for the understanding of volcanic impacts. For pre-satellite era eruptions, determination of atmospheric aerosol loading - the leading mechanism by which volcanoes impact climate - hinges upon models of aerosol dispersal and deposition based on suspected source and ice-core sulfur concentrations (Gao et al., 2007). Injection height may also determine the duration of aerosol persistence in the stratosphere, and consequently, its climate effectiveness (Toohey et al., 2019; Marshall et al., 2019; Aubry et al., 2020). Some

335 prior knowledge of the source and eruption parameters is therefore needed to refine the modelling and interpretation of climate response.

Here, our ash dispersal models enable us to constrain the minimum injection height needed for eruptions in three volcanic regions to extend tephra to Greenland. Our results demonstrate that stratospheric injection was very likely required to disperse large ash particles to northern Greenland from either Aniakchak in the high-latitudes or Popocatépetl in the tropics. These two scenarios have implications for the determination of stratospheric sulphate loading, with a considerably larger sulfur emission expected from the tropical source to account for the aerosol deposition observed in Greenland. Consequently, were this event to be attributed to Popocatépetl rather than high- (e.g., Aniakchak) or mid-latitude (e.g., Vesuvius) sources, we would anticipate a larger global mean forcing, similar to the Huaynaputina eruption of 1600 CE. Instead, an extratropical location implies an

345 event of smaller stratospheric sulfur injection and therefore lesser global climate significance, roughly equivalent to some estimates of the sulfur injection from the 1912 Katmai eruption (Stothers, 1996). Annual resolution climate records for this period are rare, but an analysis of limited tree ring records from Northern Eurasia suggests a small cooling signal associated with the eruption (Sigl et al., 2015).

350 Although inconclusive, the tephra evidence points to the eastern Aleutians as the most likely origin of the $88 \mathrm{CE}$ eruption. Whatever the source, the same volcano contributed to the volcanic signal in Greenland ice cores in $536 \mathrm{CE}$, following which there was a major climate perturbation with societal consequences (Sigl et al., 2015; Büntgen et al., 2016). Other tephras in the NEEM-2011-S1 ice core at this time illustrate that the 536 CE sulfur signal is potentially a composite of three simultaneous 
https://doi.org/10.5194/cp-2021-63

Preprint. Discussion started: 16 June 2021

(c) Author(s) 2021. CC BY 4.0 License.

\section{(c) (1)}

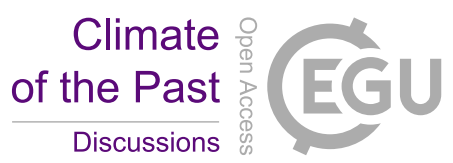

eruptions of uncertain origin (Sigl et al., 2015), confounding the estimation of atmospheric aerosol loading. Like QUB-1832/3, the large $(>50 \mu \mathrm{m})$ shard sizes in the $536 \mathrm{CE}$ ice implicate stratospheric injection. The Okmok II eruption of $43 \mathrm{BCE}$ has also been tied to climate impacts (McConnell et al., 2020), clearly demonstrating the significant forcing potential of high-latitude eruptions.

The $43 \mathrm{BCE}, 88 \mathrm{CE}$ and $536 \mathrm{CE}$ events seem to share a similar volcanic source region and magnitude (VEI 5 or greater), but their aerosol representation in Greenland ice cores is spatially divergent (Table 1). Ice-core records of cumulative volcanic sulfate deposition in Greenland for the 88 CE event are available from NEEM-2011-S1 (Sigl et al., 2015), NGRIP2 (McConnell et al., 2018), GISP2 (Zielinski, 1995), GRIP and Dye-3 (Clausen et al., 1997). These records demonstrate a strong spatial gradient in volcanic sulfate deposition following this eruption: high sulfate mass deposition is observed in northern Greenland (NEEM: $83 \mathrm{~kg} \mathrm{~km}^{-2} \mathrm{y}$ ), but only moderate deposition is recorded in central and southern Greenland (NGRIP2: $32 \mathrm{~kg} \mathrm{~km}^{-2} \mathrm{y}$; GRIP: $26 \mathrm{~kg} \mathrm{~km}^{-2} \mathrm{y}$; GISP2 $29 \mathrm{~kg} \mathrm{~km}^{-2} \mathrm{y}$; Dye 3: $\left.31 \mathrm{~kg} \mathrm{~km}^{-2} \mathrm{y}\right)$. The mean deposition (40 kg km${ }^{-2} \mathrm{y}$ ) over the five ice-core sites is much lower than the deposition following the $536 \mathrm{CE}\left(75 \mathrm{~kg} \mathrm{~km}^{-2} \mathrm{y}\right)$ or Okmok II $\left(117 \mathrm{~km}^{-2} \mathrm{y}\right)$ events. Moreover, the duration of volcanic sulfate deposition is markedly shorter ( 0.9 years) for the $88 \mathrm{CE}$ eruption compared to that of the $536 \mathrm{CE}$ (1.7 years) and Okmok II (2.3 years) events, suggesting more rapid atmospheric aerosol removal. The relative importance of other variables - duration of eruption, contributing effects of other eruptions, prior state of the climate system - cannot presently be determined.

\section{Conclusions}

The NS1-2011 revised ice-core chronology that differentiates the conspicuous, 1st century CE volcanic signal in Greenland ice from the historical age of Vesuvius is now supported by tephra evidence that demonstrates the sulfate was from an eruption other than Vesuvius. Although we have been unable to pinpoint the precise source eruption, the geochemical signature of its glass shards most strongly points to the Aleutian arc as the source region. Shard characteristics, combined with ash dispersal models, implicate a large magnitude eruption with stratospheric injection. Constraining the location and minimum eruption height of the event promises to improve the estimation of stratospheric aerosol loading and radiative forcing when combined with understanding of the dependence of aerosol lifetime on these eruption parameters (Marshall et al., 2019; Toohey et al, 2019). We note, however, that unlike notable events such as the 43 BCE Okmok II and 536 CE unidentified eruptions, the 88 CE eruption is not presently associated with any known major climatic perturbations.

Increasingly, the recognition of solar proton events in tree-ring and ice core archives is demonstrating offsets in the ice core chronology, and it is imperative that ice-core chronologies are now updated in recognition of the known dating bias in GICC05. Multi-proxy compilations (PAGES2k, LMR, PHYDA and others) in which ice-core derived $\delta^{18} \mathrm{O}$ and $\delta \mathrm{D}$ records from 385 Greenland (and also some from Antarctica) are still constrained by the erroneous 79 CE tie-point need to be updated to capture 
https://doi.org/10.5194/cp-2021-63

Preprint. Discussion started: 16 June 2021

(c) Author(s) 2021. CC BY 4.0 License.

(c) (i)

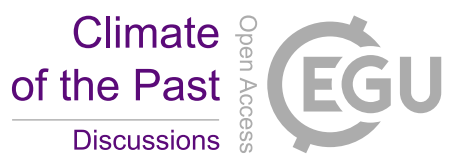

accurately natural climate variability. Previous work has demonstrated that only under the revised NS1-2011 chronology is the magnitude of post-volcanic cooling inferred from tree-ring reconstructions over the course of the last two millennia consistent (Sigl et al., 2015; Büntgen et al., 2020). Unfounded attributions of volcanic events in ice cores, irrespective of their close temporal coincidence with known eruptions, should be avoided to eliminate unconscious bias in the construction of ice core chronologies and the interpretation of volcanic impacts.

\section{Author contribution}

G.P. and M.S. devised the research. M.S. and J.R.McC. undertook ice core sampling. G.P., M.S., H.S., E.T., and M.T. wrote the paper, with input from all other authors. G.P., J.R.P., and E.T. conducted tephra analysis, and H.S. the ash-modelling. T.H. and C.S. provided reference tephra samples and advised on proximal deposits and tephra correlations.

\section{Competing interests}

The authors declare that they have no conflict of interest.

\section{Acknowledgments}

Collection and chemical analysis of the NEEM-2011-S1 core was funded by National Science Foundation (NSF) grant 0909541 to J.R.McC. NSF grant 1925417 provided additional support to J.R.McC. for this study. We thank the NEEM 400 community, for providing access to NEEM-2011-S1 ice samples. We also appreciate the assistance of the NEEM community for logistics, drilling, science, and other support. In particular, we thank S.-B. Hansen, T. Popp, D. Mandeno, M. Leonhardt, and A. Moy for drilling the NEEM S1 core. NEEM is directed and organized by the Centre of Ice and Climate at the Niels Bohr Institute and US NSF, Office of Polar Programs. It is supported by funding agencies and institutions in Belgium (FNRSCFB and FWO), Canada (NRCan/GSC), China (CAS), Denmark (FIST), France (IPEV, CNRS/INSU, CEA and ANR),

405 Germany (AWI), Iceland (RannIs), Japan (NIPR), South Korea (KOPRI), The Netherlands (NWO/ALW), Sweden (VR), Switzerland (SNF), the United Kingdom (NERC) and the USA (US NSF, Office of Polar Programs) and the EU Seventh Framework programmes Past4Future and WaterundertheIce. Work by C.S. on Popocatépetl was funded by UNAM-DGAPA and CONACYT grants. The iCRAG LA-ICP-MS facility at Trinity College Dublin is supported by SFI award 13/RC/2092. We are grateful to the Division of Petrology and Volcanology, Department of Mineral Sciences, Smithsonian Institution, for

410 making available specimens of Popocatépetl ash for analysis, and to Vera Ponomareva and Paul Albert for their comments on the tephra geochemistry. M.S. received funding from the European Research Council under the European Union's Horizon 2020 research and innovation programme (grant agreement no. 820047). This work also benefitted from participation by some authors in the Past Global Changes Volcanic Impacts on Climate and Society working group. 
https://doi.org/10.5194/cp-2021-63

Preprint. Discussion started: 16 June 2021

(c) Author(s) 2021. CC BY 4.0 License.

(c) (i)

\section{References}

Abbott, P. M., Plunkett, G., Corona, C., Chellman, N. J., McConnell, J. R., Pilcher, J. R., Stoffel, M., and Sigl, M.: Cryptotephra from the Icelandic Veiðivötn 1477 CE eruption in a Greenland ice core: confirming the dating of volcanic events in the 1450s CE and assessing the eruption's climatic impact, Clim. Past, 17, 565--585, https://doi.org/10.5194/cp-17-565-2021, 2021.

Abram, N. J., McGregor, H. V., Tierney, J. E., Evans, M. N., McKay, N. P., Kaufman, D. S., and PAGES 2k Consortium: Early onset of industrial-era warming across the oceans and continents, Nature, 536, 411-418, https://doi.org/10.1038/nature19082, 2016.

Albert, P. G., Smith, V. C., Suzuki, T., McLean, D., Tomlinson, E. L., Miyabuchi, Y., Kitaba, I., Mark, D. F., Moriwaki, H., 425 Members, S. P., and Nakagawa, T.: Geochemical characterisation of the Late Quaternary widespread Japanese tephrostratigraphic markers and correlations to the Lake Suigetsu sedimentary archive (SG06 core), Quaternary Geochron., 52, 103-131, https://doi.org/10.1016/j.quageo.2019.01.005, 2019.

Andreastuti, S. D.: Stratigraphy and geochemistry of Merapi Volcano, Central Java, Indonesia: implication for assessment of 430 volcanic hazards, Ph.D. thesis, University of Auckland, 1999.

Arana-Salinas, L., Siebe, C., and Macías, J. L.: Dynamics of the ca. $4965 \mathrm{yr}{ }^{14} \mathrm{C}$ BP "Ochre Pumice" Plinian eruption of Popocatépetl volcano, México, J. Volcanol. Geoth. Res., 192, 212-231, https://doi.org/10.1016/j.jvolgeores.2010.02.022, 2010.

Aubry, T. J., Toohey, M., Marshall, L., Schmidt, A., and Jellinek, A. M.: A new volcanic stratospheric sulfate aerosol forcing emulator (EVA_H): comparison with interactive stratospheric aerosol models, J. Geophys. Res. - Atmos., 125, D031303, https://doi.org/10.1029/2019JD031303, 2020.

440 Baillie, M. G. L.: Extreme environmental events and the linking of the tree-ring and ice-core records, in: Tree Rings, Environment, and Humanity, edited by Dean, J. S., Meko, D. M., and Swetnam, T. W., Radiocarbon, Department of Geosciences, The University of Arizona (Tucson), 703-711, 1996.

Baillie, M. G. L.: Proposed re-dating of the European ice core chronology by seven years prior to the $7^{\text {th }}$ century AD, Geophys. 445 Res. Lett., 35, L15813, https://doi.org/10.1029/2008GL034755, 2008. 
https://doi.org/10.5194/cp-2021-63

Preprint. Discussion started: 16 June 2021

(c) Author(s) 2021. CC BY 4.0 License.

(c) (i)

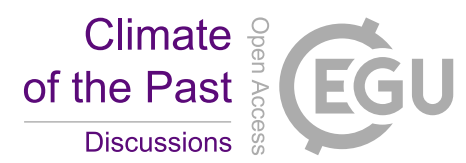

Baillie, M. G. L. and McAneney, J.: Tree ring effects and ice core acidities clarify the volcanic record of the first millennium, Clim. Past, 11, 105-114, doi:10.5194/cp-11-105-2015, 2015.

Baggenstos, D., Severinghaus, J. P., Mulvaney, R., McConnell, J. R., Sigl, M., Maselli, O., Petit, J. R., Grente, B., and Steig, E. J.: A horizontal ice core from Taylor Glacier, its implications for Antarctic climate history, and an improved Taylor Dome ice core time scale, Paleoceanography and Paleoclimatology, 33, 778-794, oi.org/10.1029/2017PA003297, 2018.

Barbante, C., Kehrwald, N. M., Marianelli, P., Vinther, B. M., Steffensen, J .P., Cozzi, G., Hammer, C. U., and Clausen, H. B.: Greenland ice core evidence of the 79 AD Vesuvius eruption, Clim. Past, 9, 1221-1232, https://doi.org/10.5194/cp-9-12212013, 2013.

Barber, K. E., Langdon, P., and Blundell, A. Dating the Glen Garry tephra: a widespread late-Holocene marker horizon in the peatlands of northern Britain, Holocene, 18, 31-43, https://doi.org/10.1177/0959683607085594, 2008.

Begét, J., Stihler, S. D., and Stone, D. B.: A 500-year-long record of tephra falls from Redoubt Volcano and other volcanoes in upper Cook Inlet, Alaska, J. Volcanol. Geoth. Res., 62, 55-67, https://doi.org/10.1016/0377-0273(94)90028-0, 1994.

Belousova, M. and Belousov, A.: Frequent basaltic Plinian eruptions in the history of Chikurachki volcano, Kurile islands,

Russia, XXVI European Geophysical Society (EGS) General Assembly, Nice, France, March 2001, 2001.

Brown, S. K., Crosweller, H. S., Sparks, R. S. J., Cottrell, E., Deligne, N. I., Guerrero, N. O., Hobbs, L., Kiyosugi, K., Loughlin, S. C., Siebert, L., and Takarada, S.: Characterisation of the Quaternary eruption record: analysis of the Large Magnitude Explosive Volcanic Eruptions (LaMEVE) database, J. Appl. Volcanol., 3, 5, https://doi.org/10.1186/2191-5040-3-5, 2014.

Buizert, C., Sigl, M., Severi, M., Markle, B. R., Wettstein, J. J., McConnell, J. R., Pedro, J. B., Sodemann, H., Goto-Azuma, K., Kawamura, K., Fujita, S., Motoyama, H., Hirabayashi, M., Uemura, R., Stenni, B., Parrenin, F., He, F., Fudge, T. J., and Steig, E. J.: Abrupt ice-age shifts in southern westerly winds and Antarctic climate forced from the north, Nature, 563, 681685, https://doi.org/10.1038/s41586-018-0727-5, 2018.

Büntgen, U., Myglan, V. S., Ljungqvist, F. C., McCormick, M., Di Cosmo, N., Sigl, M., Jungclaus, J., Wagner, S., Krusic, P. J., Esper, J., Kaplan, J. O., de Vaan, M. A. C., Luterbacher, J., Wacker, L., Tegel, W., and Kirdyanov, A. V.: Cooling and societal change during the Late Antique Little Ice Age from 536 to around 660 AD, Nat. Geosci., 9, 231-236, https://doi.org/10.1038/ngeo2652, 2016. 
https://doi.org/10.5194/cp-2021-63

Preprint. Discussion started: 16 June 2021

(c) Author(s) 2021. CC BY 4.0 License.

(c) (i)

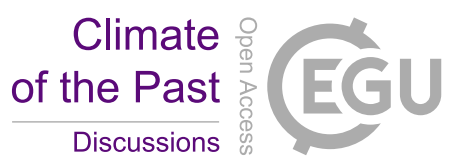

480

Büntgen, U., Arseneault, D., Boucher, É., Churakova, O. V., Gennaretti, F., Crivellaro, A., Hughes, M. K., Kirdyanov, A. V., Klippel, L., Krusic, P. J., Linderholm, H. W., Ljungqvist, F. C., Ludescher, J., McCormick, M., Myglan, V. S., Nicolussi, K., Piermattei, A., Oppenheimer, C., Reinig, F., Sigl, M., Vaganov, E. A., and Esper, J.: Prominent role of volcanism in Common Era climate variability and human history, Dendrochronologia, 64, 125757, https://doi.org/10.1016/j.dendro.2020.125757, 4852020.

Burden, R. E., Phillips, J. C., and Hincks, T. K.: Estimating volcanic plume heights from depositional clast size, J. Geophys. Res.: Sol. Ea., 116, B11206, https://doi.org/10.1029/2011JB008548, 2011.

490 Carey, S. and Sparks, R. S. J.: Quantitative models of the fallout and dispersal of tephra from volcanic eruption columns, B. Volcanol., 48, 109-125, https://doi.org/10.1007/BF01046546, 1986.

Cassidy, M., Taylor, R. N., Palmer, M. R., Cooper, R. J., Stenlake, C., and Trofimovs, J.: Tracking the magmatic evolution of island arc volcanism: Insights from a high-precision $\mathrm{Pb}$ isotope record of Montserrat, Lesser Antilles, Geochem. Geophy.

495 Geosy., 13, Q05003, https://doi.org/10.1029/2012GC004064, 2012.

Child, J.K., Begét, J.E., and Werner, A.: Three Holocene tephras identified in lacustrine sediment cores from the Wonder Lake area, Denali National Park and Preserve, Alaska, USA, Arctic Alpine Res., 30, 89-95, https://doi.org/10.1080/00040851.1998.12002879. 1998.

500

Clausen, H. B., Hammer, C. U., Hvidberg, C. S., DahlJensen, D., Steffensen, J. P., Kipfstuhl, J., and Legrand, M.: A comparison of the volcanic records over the past 4000 years from the Greenland Ice Core Project and Dye 3 Greenland Ice Cores, J. Geophys. Res. - Oceans, 102, 26707-26723, https://doi.org/10.1029/97JC00587 1997.

505 Cole-Dai, J., Ferris, D. G., Kennedy, J. A., Sigl, M., McConnell, J. R., Fudge, T. J., Geng, L., Maselli, O. J., Taylor, K. C., and Souney, J. M.: Comprehensive record of volcanic eruptions in the Holocene (11,000 years) from the WAIS Divide, Antarctica ice core, J. Geophys. Res. - Atmos., 126, e2020JD032855, https://doi.org/10.1029/2020JD032855, 2021.

Coulter, S. E., Pilcher, J. R., Plunkett, G., Baillie, M., Hall, V. A., Steffensen, J. P., Vinther, B. M., Clausen, H. B., and Johnsen, 510 S. J.: Holocene tephras highlight complexity of volcanic signals in Greenland ice cores, J. Geophys. Res., 117, D21303, https://doi.org/10.1029/2012JD017698, 2012. 
https://doi.org/10.5194/cp-2021-63

Preprint. Discussion started: 16 June 2021

(c) Author(s) 2021. CC BY 4.0 License.

(c) (i)

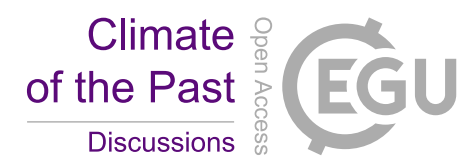

Crowley, T. J.: Causes of climate change over the past 1000 years, Science, 289, 270-277, 10.1126/science.289.5477.270, 2000.

Davies, L. J., Jensen, B. J., Froese, D. G., and Wallace, K. L.: Late Pleistocene and Holocene tephrostratigraphy of interior Alaska and Yukon: Key beds and chronologies over the past 30,000 years, Quaternary Sci. Rev., 146, 28-53, https://doi.org/10.1016/j.quascirev.2016.05.026, 2016.

de Leeuw, J., Schmidt, A., Witham, C. S., Theys, N., Taylor, I. A., Grainger, R. G., Pope, R. J., Haywood, J., Osborne, M., and Kristiansen, N. I.: The 2019 Raikoke volcanic eruption: Part 1 Dispersion model simulations and satellite retrievals of volcanic sulfur dioxide, Atmos. Chem. Phys. Discuss., https://https://doi.org/10.5194/acp-2020-889, in review, 2020.

Dunbar, N. W., Iverson, N. A., Van Eaton, A. R., Sigl, M., Alloway, B. V., Kurbatov, A. V., Mastin, L. G., McConnell, J. R., and Wilson, C. J. N.: New Zealand supereruption provides time marker for the Last Glacial Maximum in Antarctica, Sci. Rep., 7, 12238, https://doi.org/10.1038/s41598-017-11758-0, 2017.

DeVitre, C. L., Gazel, E., Allison, C. M., Soto, G., Madrigal, P., Alvarado, G. E., and Lücke, O. H.: Multi-stage chaotic magma mixing at Turrialba volcano, J. Volcanol. Geoth. Res., 381, 330-346, https://doi.org/10.1016/j.jvolgeores.2019.06.011, 2019.

Di Piazza, A., Rizzo, A. L., Barberi, F., Carapezza, M. L., De Astis, G., Romano, C., and Sortino, F.: Geochemistry of the mantle source and magma feeding system beneath Turrialba volcano, Costa Rica, Lithos, 232, 319-335, https://doi.org/10.1016/j.lithos.2015.07.012, 2015.

DuFrane, S. A., Turner, S., Dosseto, A., and Van Soest, M.: Reappraisal of fluid and sediment contributions to Lesser Antilles magmas, Chem. Geol., 265, 272-278, https://doi.org/10.1016/j.chemgeo.2009.03.030, 2009.

Dugmore, A. J., Newton, A. J., Larsen, G., and Cook, G. T.: Tephrochronology, environmental change and the Norse settlement of Iceland, Environ. Archaeol., 5, 21-34, https://doi.org/10.1179/env.2000.5.1.21, 2000.

Foit, F. F., Gavin, D. G., and Hu, F. S.: The tephra stratigraphy of two lakes in south-central British Columbia, Canada and its implications for mid-late Holocene volcanic activity at Glacier Peak and Mount St. Helens, Washington, USA, Can. J. Earth Sci., 41, 1401-1410, https://doi.org/10.1139/e04-081, 2004.

545 Gao, C., Oman, L., Robock, A., and Stenchikov, G. L.: Atmospheric volcanic loading derived from bipolar ice cores accounting for the spatial distribution of volcanic deposition, J. Geophys. Res., 112, D09109, doi:10.1029/2006JD007461., 2007. 
https://doi.org/10.5194/cp-2021-63

Preprint. Discussion started: 16 June 2021

(c) Author(s) 2021. CC BY 4.0 License.

(c) (i)

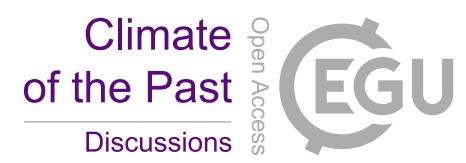

Gao, C. C., Ludlow, F., Stine, A., Robock, A., Pan, Y., and Sigl, M.: Dynastic collapse in China and past volcanism, Communications Earth and Environment, submitted.

550

Garrison, J. M., Davidson, J. P., Hall, M., and Mothes, P.: Geochemistry and petrology of the most recent deposits from Cotopaxi Volcano, Northern Volcanic Zone, Ecuador, J. Petrol., 52, 1641-1678, https://doi.org/10.1093/petrology/egr023, 2011.

555 George, R., Turner, S., Hawkesworth, C., Morris, J., Nye, C., Ryan, J., and Zheng, S. H.: Melting processes and fluid and sediment transport rates along the Alaska-Aleutian arc from an integrated U-Th-Ra-Be isotope study, J. Geophys. Res.: Sol. Ea., 108, B52252, https://doi.org/10.1029/2002JB001916, 2003.

Gjerløw, E., Haflidason, H., and Pedersen, R. B.: Holocene explosive volcanism of the Jan Mayen (island) volcanic province, 560 North-Atlantic, J. Volcanol. Geoth. Res., 321, 31-43, https://doi.org/10.1016/j.jvolgeores.2016.04.025, 2016.

Global Volcanism Program: Volcanoes of the World, v. 4.8.4, edited by: Venzke, E., Smithsonian Institution: https://doi.org/10.5479/si.GVP.VOTW4-2013, last access 07 Dec 2019, 2013.

565 Hammer, C. U., Clausen, H. B., and Dansgaard, W.: Greenland ice sheet evidence of post-glacial volcanism and its climatic impact, Nature, 288, 230-235, https://doi.org/10.1038/288230a0, 1980.

Hammer, C. U., Kurat, G., Hoppe, P., Grum, W., and Clausen, H. B.: Thera eruption date 1645BC confirmed by new ice core data? in: The Synchronisation of Civilisations in the Eastern Mediterranean in the Second Millennium B.C. Proceedings of the SCIEM 2000 - EuroConference Haindorf, May 2001, Vienna, edited by Bietak, M., Verlag der Osterreichischen Akademie der Wissenschaften, Band XXIX, 87-93, 2003.

Hasegawa T., Nakagawa M., Yoshimoto M., Ishizuka Y., Hirose W., Seki S., Ponomareva V., and Rybin A.: Tephrostratigraphy and petrological study of Chikurachki and Fuss volcanoes, western Paramushir Island, northern Kurile 575 Islands: Evaluation of Holocene eruptive activity and temporal change of magma system, Quaternary Int., 246, 278-297, https://doi.org/10.1016/j.quaint.2011.06.047, 2011.

Helama, S., Stoffel, M., Hall, R. J., Jones, P. D., Arppe, L., Matskovsky, V. V., Timonen, M., Nojd, P., Mielikainen, K., and Oinonen, M.: Recurrent transitions to Little Ice Age-like climatic regimes over the Holocene, Clim. Dynam., doi: 10.1007/s00382-021-05669-0, 2021. 
https://doi.org/10.5194/cp-2021-63

Preprint. Discussion started: 16 June 2021

(c) Author(s) 2021. CC BY 4.0 License.

\section{(c) (1)}

Climate
of the Past

Discussions

Howe, T. M., Lindsay, J. M., Shane, P., Schmitt, A. K., and Stockli, D. F.: Re-evaluation of the Roseau Tuff eruptive sequence and other ignimbrites in Dominica, Lesser Antilles, J. Quaternary Sci., 29, 531-546, https://doi.org/10.1002/jqs.2723, 2014.

585 Howe, T. M., Lindsay, J. M., and Shane, P.: Evolution of young andesitic-dacitic magmatic systems beneath Dominica, Lesser Antilles, J. Volcanol. Geoth. Res., 297, 69-88. https://doi.org/10.1016/j.jvolgeores.2015.02.009, 2015.

Jensen, B. J. L., Pyne-O’Donnell, S., Plunkett, G., Froese, D. G., Hughes, P. D. M., Sigl, M., McConnell, J. R., Amesbury, M. J., Blackwell, P. G., van den Bogaard, C., Buck, C. E., Charman, D. J., Clague, J. J., Hall, V. A., Koch, J., Mackay, H., Mallon, G., McColl, L., and Pilcher, J. R.: Transatlantic distribution of the Alaskan White River Ash, Geology, 42, 875-878, https://doi.org/10.1130/G35945.1, 2014.

Kaufman, D. S., Jensen, B. J. L., Reyes, A. V., Schiff, C. J., Froese, D. G., and Pearce, N. J. G.: Late Quaternary tephrostratigraphy, Ahklun Mountains, SW Alaska, J. Quaternary Sci., 27, 344-359, https://doi.org/10.1002/jqs.1552, 2012.

Kaufman, D., McKay, N., Routson, C., Erb, M., Davis, B., Heiri, O., Jaccard, S., Tierney, J., Datwyler, C., Axford, Y., Brussel, T., Cartapanis, O., Chase, B., Dawson, A., de Vernal, A., Engels, S., Jonkers, L., Marsicek, J., Moffa-Sanchez, P., Morrill, C., Orsi, A., Rehfeld, K., Saunders, K., Sommer, P. S., Thomas, E., Tonello, M., Toth, M., Vachula, R., Andreev, A., Bertrand, S., Biskaborn, B., Bringue, M., Brooks, S., Caniupan, M., Chevalier, M., Cwynar, L., Emile-Geay, J., Fegyveresi, J., Feurdean,

600 A., Finsinger, W., Fortin, M. C., Foster, L., Fox, M., Gajewski, K., Grosjean, M., Hausmann, S., Heinrichs, M., Holmes, N., Ilyashuk, B., Ilyashuk, E., Juggins, S., Khider, D., Koinig, K., Langdon, P., Larocque-Tobler, I., Li, J. Y., Lotter, A., Luoto, T., Mackay, A., Magyari, E., Malevich, S., Mark, B., Massaferro, J., Montade, V., Nazarova, L., Novenko, E., Paril, P., Pearson, E., Peros, M., Pienitz, R., Plociennik, M., Porinchu, D., Potito, A., Rees, A., Reinemann, S., Roberts, S., Rolland, N., Salonen, S., Self, A., Seppa, H., Shala, S., St-Jacques, J. M., Stenni, B., Syrykh, L., Tarrats, P., Taylor, K., van den Bos, V.,

605 Velle, G., Wahl, E., Walker, I., Wilmshurst, J., Zhang, E. L., and Zhilich, S.: A global database of Holocene paleotemperature records, Sci Data, 7, 115, https://doi.org/10.1038/s41597-020-0445-3 2020.

Konecky, B. L., McKay, N. P., Churakova, O. V., Comas-Bru, L., Dassie, E. P., DeLong, K. L., Falster, G. M., Fischer, M. J., Jones, M. D., Jonkers, L., Kaufman, D. S., Leduc, G., Managave, S. R., Martrat, B., Opel, T., Orsi, A. J., Partin, J. W., Sayani, 610 H. R., Thomas, E. K., Thompson, D. M., Tyler, J. J., Abram, N. J., Atwood, A. R., Cartapanis, O., Conroy, J. L., Curran, M. A., Dee, S. G., Deininger, M., Divine, D. V., Kern, Z., Porter, T. J., Stevenson, S. L., von Gunten, L., and Iso2k, PAGES Consortium.: The Iso2k database: a global compilation of paleo- $\delta^{18} \mathrm{O}$ and $\delta^{2} \mathrm{H}$ records to aid understanding of Common Era climate, Earth Syst. Sci. Data, 12, 2261-2288, https://doi.org/10.5194/essd-12-2261-2020, 2020. 
https://doi.org/10.5194/cp-2021-63

Preprint. Discussion started: 16 June 2021

(c) Author(s) 2021. CC BY 4.0 License.

(c) (i)

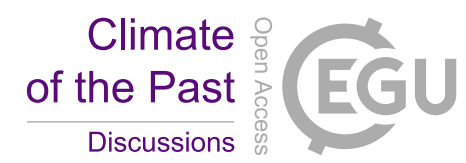

615 Kutterolf, S., Freundt, A., Perez, W., Mörz, T., Schacht, U., Wehrmann, H., and Schmincke, H. U.: Pacific offshore record of plinian arc volcanism in Central America: 1. Along-arc correlations, Geochem. Geophys. Geosy., 9, Q02S01, https://doi.org/10.1029/2007GC001631, 2008.

Kyle, P. R., Ponomareva, V. V. and, Rourke Schluep, R.: Geochemical characterization of marker tephra layers from major

620 Holocene eruptions in Kamchatka, Russia, Int. Geol. Rev., 53, 1059-1097, https://doi.org/10.1080/00206810903442162, 2011.

Labanieh, S., Chauvel, C., Germa, A., Quidelleur, X., and Lewin, E.: Isotopic hyperbolas constrain sources and processes under the Lesser Antilles arc, Earth Plan. Sci. Lett., 298, 35-46, https://doi.org/10.1093/petrology/egs055, 2010.

Le Bas, M. J., Le Maitre, R. W., Streckeisen, A., and Zanettin, B.: A chemical classification of volcanic rocks on the total alkali-silica diagram, J. Petrol., 27, 745-750, https://doi.org/10.1093/petrology/27.3.745, 1986.

Legros, F.: Tephra stratigraphy of Misti volcano, Peru, J. S. Am. Earth Sci., 14, 15-29, https://doi.org/10.1016/S0895$630 \quad 9811(00) 00062-6,2001$.

Larsen, G., Newton, A. J., Dugmore, A. J., and Vilmundardóttir, E. G.: Geochemistry, dispersal, volumes and chronology of Holocene silicic tephra layers from the Katla volcanic system, Iceland, J. Quaternary Sci., 16, 119-132, https://doi.org/10.1002/jqs.587, 2001.

635

Macías, J. L., Espíndola, J. M., Garcia-Palomo, A., Scott, K. M., Hughes, S., and Mora, J. C.: Late Holocene Peléan-style eruption at Tacaná volcano, Mexico and Guatemala: Past, present, and future hazards, Geol. Soc. Am. Bull., 112, 1234-1249, https://doi.org/10.1130/0016-7606(2000)112<1234:LHPEAT>2.0.CO;2, 2000.

640 Manning, J. G., Ludlow, F., Stine, A. R., Boos, W. R., Sigl, M., and Marlon, J. R.: Volcanic suppression of Nile summer flooding triggers revolt and constrains interstate conflict in ancient Egypt, Nat. Commun., 8, 900, https://doi.org/10.1038/s41467-017-00957-y, 2017.

Marshall, L., Johnson, J. S., Mann, G. W., Lee, L., Dhomse, S. S., Regayre, L., Yoshioka, M., Carslaw, K. S., and Schmidt, 645 A.: Exploring how eruption source parameters affect volcanic radiative forcing using statistical emulation, J. Geophys. Res. Atmos., 124, 964-985, doi:10.1029/2018JD028675, 2019. 
https://doi.org/10.5194/cp-2021-63

Preprint. Discussion started: 16 June 2021

(c) Author(s) 2021. CC BY 4.0 License.

(c) (i)

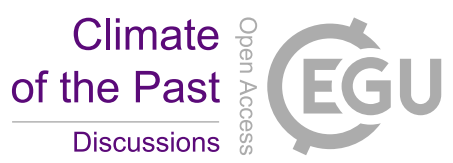

Martel, C. and Poussineau, S.: Diversity of eruptive styles inferred from the microlites of Mt Pelée andesite (Martinique, Lesser Antilles), J. Volcanol. Geoth. Res., 166, 233-254, https://doi.org/10.1016/j.jvolgeores.2007.08.003, 2007.

650

Mastin, L. G., Van Eaton, A. R., and Schwaiger, H. F.: A probabilistic assessment of tephra-fall hazards at Hanford, Washington, from a future eruption of Mount St. Helens, U.S. Geological Survey Open-File Report 2020-1133, 54 pp., https://doi.org/10.3133/ofr20201133, 2020.

McConnell, J. R., Lamorey, G. W., Lambert, S. W., and Taylor, K. C.: Continuous ice-core chemical analyses using Inductively coupled plasma mass spectrometry, Environ. Sci. Technol., 36, 7-11, https://doi.org/10.1021/es011088z, 2002.

McConnell, J. R., Burke, A., Dunbar, N. W., Köhler, P., Thomas, J. L., Arienzo, M. M., Chellman, N. J., Maselli, O. J., Sigl, M., Adkins, J. F., and Baggenstos, D.: Synchronous volcanic eruptions and abrupt climate change 17.7 ka plausibly linked by stratospheric ozone depletion, P. Natl. Acad. Sci. USA, 114, 10035-10040, https://doi.org/10.1073/pnas.1705595114, 2017.

McConnell, J. R., Wilson, A. I., Stohl, A., Arienzo, M. M., Chellman, N. J., Eckhardt, S., Thompson, E. M., Pollard, A. M., and Steffensen, J. P.: Lead pollution recorded in Greenland ice indicates European emissions tracked plagues, wars, and imperial expansion during antiquity, P. Natl. Acad. Sci. USA, 115, 5726-5731, doi: 10.1073/pnas.1721818115, 2018.

665

McConnell, J. R., Chellman, N.J., Wilson, A. I., Stohl, A., Arienzo, M. M., Eckhardt, S., Fritzsche, D., Kipfstuhl, S., Opel, T., Place, P. F., and Steffensen, J. P.: Pervasive Arctic lead pollution suggests substantial growth in Medieval silver production modulated by plague, climate and conflict, Proc. Natl. Acad. Sci. USA, 116, 14910-14915, doi:10.1073/pnas.1904515116, 2019.

670

McConnell, J. R., Sigl, M., Plunkett, G., Burke, A., Kim, W. M., Raible, C. C., Wilson, A. I., Manning, J. G., Ludlow, F. M., Chellman, N. J., Innes, H. M., Yang, Z., Larsen, J. F., Schaefer, J. R., Kipfstuhl, S., Mojtabavi, S., Wilhelms, F., Opel, T., Meyer, H., and Steffensen, J. P.: Extreme climate after massive eruption of Alaska's Okmok volcano in 43 BCE and effects on the late Roman Republic and Ptolemaic Kingdom, P. Natl. Acad. Sci. USA, 117, 15443-15449, https://doi.org/10.1073/pnas.2002722117, 2020.

McKay, N. P. and Kaufman, D. S.: An extended Arctic proxy temperature database for the past 2,000 years, Sci. Data, 1, 140026, https://doi.org/10.1038/sdata.2014.26, 2014.

680 Mojtabavi, S., Wilhelms, F., Cook, E., Davies, S. M., Sinnl, G., Jensen, M. S., Dahl-Jensen, D., Svensson, A., Vinther, B. M., Kipfstuhl, S., Jones, G., Karlsson, N. B., Faria, S. H., Gkinis, V., Kjaer, H. A., Erhardt, T., Berben, S. M. P., Nisancioglu, K. 
https://doi.org/10.5194/cp-2021-63

Preprint. Discussion started: 16 June 2021

(c) Author(s) 2021. CC BY 4.0 License.

(c) (i)

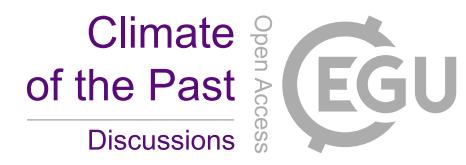

H., Koldtoft, I., and Rasmussen, S. O.: A first chronology for the East Greenland Ice-core Project (EGRIP) over the Holocene and last glacial termination, Clim. Past, 16, 2359-2380, https://doi.org/10.5194/cp-16-2359-2020, 2020.

685 Mora, J. C., Gardner, J. E., Macías, J. L., Meriggi, L., and Santo, A. P.: Magmatic controls on eruption dynamics of the 1950 yr BP eruption of San Antonio Volcano, Tacaná Volcanic Complex, Mexico-Guatemala, J. Volcanol. Geoth. Res., 262, 134152, https://doi.org/10.1016/j.jvolgeores.2013.06.002, 2013.

Németh, K., Cronin, S. J., Stewart, R. B., and Charley, D.: Intra-and extra-caldera volcaniclastic facies and geomorphic characteristics of a frequently active mafic island-arc volcano, Ambrym Island, Vanuatu, Sediment. Geol., 220, 256-270, https://doi.org/10.1016/j.sedgeo.2009.04.019, 2009.

Neukom, R., Steiger, N., Gomez-Navarro, J. J., Wang, J. H., and Werner, J. P.: No evidence for globally coherent warm and cold periods over the preindustrial Common Era, Nature, 571, 550-554, https://doi.org/10.1038/s41586-019-1401-2, 2019.

Newnham, R. M., Lowe, D. J., and Wigley, G. N. A.: Late Holocene palynology and palaeovegetation of tephra-bearing mires at Papamoa and Waihi Beach, western Bay of Plenty, North Island, New Zealand, J. Roy. Soc. New Zeal., 25, 283-300, https://doi.org/10.1080/03014223.1995.9517490, 1995.

700 Óladóttir, B.A., Larsen, G., and Sigmarsson, O.: Holocene volcanic activity at Grímsvötn, Bárdarbunga and Kverkfjöll subglacial centres beneath Vatnajökull, Iceland, Bull. Volcanol., 73, 1187-1208, https://doi.org/10.1007/s00445-011-0461-4, 2011.

Oppenheimer, C., Orchard, A., Stoffel, M., Newfield, T. P., Guillet, S., Corona, C., Sigl, M., Di Cosmo, N., and Büntgen, U.: 705 The Eldgjá eruption: timing, long-range impacts and influence on the Christianisation of Iceland, Climatic Change, 147, 369381, https://doi.org/10.1007/s10584-018-2171-9, 2018.

PAGES 2k Consortium: Continental-scale temperature variability during the past two millennia, Nat. Geosci., 6, 339-346, https://doi.org/10.1038/ngeo1797, 2013.

PAGES2k Consortium: A global multiproxy database for temperature reconstructions of the Common Era, Sci. Data, 4, https://doi.org/10.1038/sdata.2017.88, 2017.

PAGES 2k Consortium: Consistent multidecadal variability in global temperature reconstructions and simulations over the 715 Common Era, Nat. Geosci., 12, 643-649, https://doi.org/ 10.1038/s41561-019-0400-0, 2019. 
https://doi.org/10.5194/cp-2021-63

Preprint. Discussion started: 16 June 2021

(c) Author(s) 2021. CC BY 4.0 License.

(c) (i)

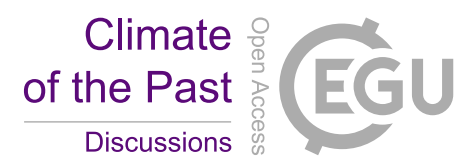

Pearce, J. A. 1983: Role of the sub-continental lithosphere in magma genesis at active continental margins. In Continental Basalts and Mantle Xenoliths, edited by: Hawkesworth, C. J., and Norry, M. J., Shiva Publications, Nantwich, 230-249, 1983.

Plunkett, G., Coulter, S. E., Ponomareva, V. V., Blaauw, M., Klimaschewski, A., and Hammarlund, D.: Distal tephrochronology in volcanic regions: Challenges and insights from Kamchatkan lake sediments, Global Planet. Change, 134, 26-40, https://doi.org/10.1016/j.gloplacha.2015.04.006, 2015.

Plunkett, G., Pearce, N. J., McConnell, J., Pilcher, J., Sigl, M., and Zhao, H.: Trace element analysis of Late Holocene tephras from Greenland ice cores, Quaternary Newsletter, 143, 10-21, 2017.

Plunkett, G., Sigl, M., Schwaiger, H., Tomlinson, E. Toohey, M., McConnell, J. R., Pilcher, J. R., Hasegawa, T., and Siebe, C.: Ash3d simulation outputs of ash deposition from hypothetical eruptions of Aniakchak (Alaska), Chikurachki (Kurile Islands) and Popocatepétl (Mexico), Zenodo, http://doi.org/10.5281/zenodo.4888030, 2021.

Plunkett, G., Sigl, M., Pilcher, J. R., McConnell, J. R., Chellman, N., Steffensen, J. P., and Büntgen, U.: Smoking guns and volcanic ash: the importance of sparse tephras in Greenland ice cores, Polar Res., 39, 3511, https://doi.org/10.33265/polar.v39.3511, 2020.

735 Ponomareva, V. V., Portnyagin, M., Pevzner, M., Blaauw, M., Kyle, P., and Derkachev, A.: Tephra from andesitic Shiveluch volcano, Kamchatka, NW Pacific: chronology of explosive eruptions and geochemical fingerprinting of volcanic glass, Int. J. Earth Sci., 104, 1459-1482, doi:10.1007/s00531-015-1156-4, 2015.

Ponomareva, V., Portnyagin, M., Pendea, I. F., Zelenin, E., Bourgeois, J., Pinegina, T., and Kozhurin, A.: A full Holocene 740 tephrochronology for the Kamchatsky Peninsula region: Applications from Kamchatka to North America, Quaternary Sci. Rev., 168, 101-122, https://doi.org/10.1016/j.quascirev.2017.04.031, 2017.

Preece, S. J., McGimsey, R. G., Westgate, J. A., Pearce, N. J. G., Hart, W. K., and Perkins, W. T.: Chemical complexity and source of the White River Ash, Alaska and Yukon, Geosphere, 10, 1020-1042, https://doi.org/10.1130/GES00953.1, 2014.

Rasmussen, S. O., Abbott, P. M., Blunier, T., Bourne, A. J., Brook, E., Buchardt, S. L., Buizert, C., Chappellaz, J., Clausen, H. B., Cook, E., Dahl-Jensen, D., Davies, S. M., Guillevic, M., Kipfstuhl, S., Laepple, T., Seierstad, I. K., Severinghaus, J. P., Steffensen, J. P., Stowasser, C., Svensson, A., Vallelonga, P., Vinther, B. M., Wilhelms, F., and Winstrup, M.: A first 
https://doi.org/10.5194/cp-2021-63

Preprint. Discussion started: 16 June 2021

(c) Author(s) 2021. CC BY 4.0 License.

(c) (i)

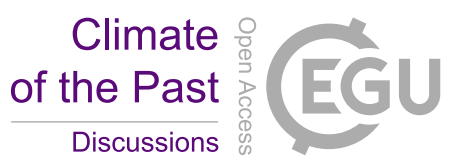

chronology for the North Greenland Eemian Ice Drilling (NEEM) ice core, Clim. Past, 9, 2713-2730, https://doi.org/10.5194/cp-9-2713-2013, 2013.

Rasmussen, S. O., Bigler, M., Blockley, S. P., Blunier, T., Buchardt, S. L., Clausen, H. B., Cvijanovic, I., Dahl-Jensen, D., Johnsen, S. J., Fischer, H., Gkinis, V., Guillevic, M., Hoek, W. Z., Lowe, J. J., Pedro, J. B., Popp, T., Seierstad, I. K., Steffensen, J. P., Svensson, A. M., Vallelonga, P., Vinther, B. M., Walker, M. J. C., Wheatley, J. J., and Winstrup, M.: A stratigraphic framework for abrupt climatic changes during the Last Glacial period based on three synchronized Greenland ice-core records: refining and extending the INTIMATE event stratigraphy, Quaternary Sci. Rev., 106, 14-28, https://doi.org/10.1016/j.quascirev.2014.09.007 2014.

Reuther, J., Potter, B., Coffman, S., Smith, H., and Bigelow, N.: 2020 Revisiting the Timing of the Northern Lobe of the White

River Ash Volcanic Event in Eastern Alaska and Western Yukon, Radiocarbon, 62, 169-188, https://doi.org/10.1017/RDC.2019.110, 2020.

Riehle, J. R.: A reconnaissance of the major Holocene tephra deposits in the upper Cook Inlet region, Alaska, J. Volcanol. Geoth. Res., 26, 37-74, https://doi.org/10.1016/0377-0273(85)90046-0, 1985.

Robin, C., Eissen, J. P. and Monzier, M.: Giant tuff cone and 12-km-wide associated caldera at Ambrym Volcano (Vanuatu, New Hebrides Arc), J. Volcanol. Geoth. Res., 55, 225-238, https://doi.org/10.1016/0377-0273(93)90039-T, 1993.

Rougier, J., Sparks, S. R., and Cashman, K. V.: Global recording rates for large eruptions, J. Appl. Volcanol., 5, 11, https://doi.org/10.1186/s13617-016-0051-4, 2016.

Samaniego, P., Robin, C., Chazot, G., Bourdon, E., and Cotten, J.: Evolving metasomatic agent in the Northern Andean subduction zone, deduced from magma composition of the long-lived Pichincha volcanic complex (Ecuador), Contrib. Mineral. Petr., 160, 239-260, https://doi.org/10.1007/s00410-009-0475-5, 2010.

Santacroce, R., Cioni, R., Marianelli, P., Sbrana, A., Sulpizio, R., Zanchetta, G., Donahue, D. J., and Joron, J. L.: Age and whole rock-glass compositions of proximal pyroclastics from the major explosive eruptions of Somma-Vesuvius: A review as a tool for distal tephrostratigraphy, J. Volcanol. Geoth. Res., 177, 1-18, https://doi.org/10.1016/j.jvolgeores.2008.06.009, 2008.

Schurer, A. P., Hegerl, G. C., Mann, M. E., Tett, S. F. B., and Phipps, S. J.: Separating forced from chaotic climate variability over the past millennium, J. Clim., 26, 6954-6973, doi:10.1175/JCLI-D-12-00826.1, 2013. 
https://doi.org/10.5194/cp-2021-63

Preprint. Discussion started: 16 June 2021

(c) Author(s) 2021. CC BY 4.0 License.

(c) (i)

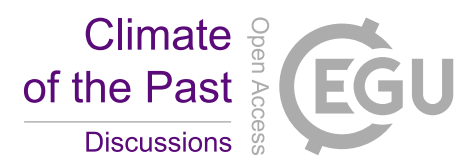

Schwaiger, H., Denlinger, R., and Mastin, L. G.: Ash3d: a finite-volume, conservative numerical model for ash transport and tephra deposition, J. Geophys. Res., 117, B04204, doi:10.1029/2011JB008968, 2012.

Siebe, C. and Macías, J.L.: Volcanic hazards in the Mexico City metropolitan area from eruptions at Popocatépetl, Nevado de Toluca, and Jocotitlán stratovolcanoes and monogenetic scoria cones in the Sierra Chichinautzin Volcanic Field, Geological Society of America Special Paper 402, Penrose Conference Series, 253-329, https://doi.org/10.1130/2004.VHITMC.PFG, 7902004.

Siebe, C., Abrams, M., Luis Macías, J., and Obenholzner, J.: Repeated volcanic disasters in Prehispanic time at Popocatépetl, central Mexico: Past key to the future? Geology 24, 399-402, https://doi.org/10.1130/00917613(1996)024<0399:RVDIPT>2.3.CO;2, 1996.

Siebe, C., Salinas, S., Arana-Salinas, L., Macías, J. L., Gardner, J., and Bonasia, R.: The 23,500 y 14C BP White Pumice Plinian eruption and associated debris avalanche and Tochimilco lava flow of Popocatépetl volcano, México, J. Volcanol. Geoth. Res., 333, 66-95, https://doi.org/10.1016/j.jvolgeores.2017.01.011, 2017.

800 Siebert, L., Simkin, T., and Kimberly, P.: Volcanoes of the World (third edition), University of California Press, Berkeley, 2011.

Seierstad, I. K., Abbott, P. M., Bigler, M., Blunier, T., Bourne, A. J., Brook, E., Buchardt, S. L., Buizert, C., Clausen, H. B., Cook, E., Dahl-Jensen, D., Davies, S. M., Guillevic, M., Johnsen, S. J., Pedersen, D. S., Popp, T. J., Rasmussen, S. O., 805 Severinghaus, J. P., Svensson, A., and Vinther, B. M.: Consistently dated records from the Greenland GRIP, GISP2 and NGRIP ice cores for the past 104 ka reveal regional millennial-scale delta O-18 gradients with possible Heinrich event imprint, Quaternary Sci. Rev., 106, 29-46, https://doi.org/10.1016/j.quascirev.2014.10.032, 2014.

Sigl, M., McConnell, J.R., Layman, L., Maselli, O., McGwire, K., Pasteris, D., Dahl-Jensen, D., Steffensen, J.P., Vinther, B., 810 Edwards, R., and Mulvaney, R.: A new bipolar ice core record of volcanism from WAIS Divide and NEEM and implications for climate forcing of the last 2000 years, J. Geophys. Res. - Atmos., 118, 1151-1169, https://doi.org/10.1029/2012JD018603, 2013.

Sigl, M., Winstrup, M., McConnell, J. R., Welten, K. C., Plunkett, G., Ludlow, F., Büntgen, U., Caffee, M., Chellman, N., 815 Dahl-Jensen, D., Fischer, H., Kipfstuhl, S., Kostick, C., Maselli, O. J., Mekhaldi, F., Mulvaney, R., Muscheler, R., Pasteris, 
https://doi.org/10.5194/cp-2021-63

Preprint. Discussion started: 16 June 2021

(c) Author(s) 2021. CC BY 4.0 License.

(c) (i)

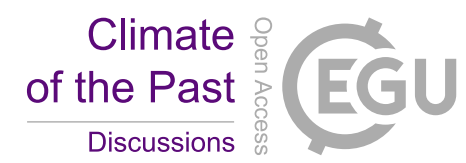

D. R., Pilcher, J. R., Salzer, M., Schüpbach, S., Steffensen, J. P., Vinther, B. M., and Woodruff, T. E.: Timing and climate forcing of volcanic eruptions for the past 2,500 years, Nature, 523, 543-549, https://doi.org/10.1038/nature14565, 2015.

Sigl, M., Fudge, T.J., Winstrup, M., Cole-Dai, J., Ferris, D., McConnell, J.R., Taylor, K.C., Welten, K.C., Woodruff, T.E., Adolphi, F., Bisiaux, M., Brook, E.J., Buizert, C., Caffee, M.W., Dunbar, N.W., Edwards, R., Geng, L., Iverson, N., Koffman, B., Layman, L., Maselli, O.J., McGwire, K., Muscheler, R., Nishiizumi, K., Pasteris, D.R., Rhodes, R.H., and Sowers, T.A.: The WAIS Divide deep ice core WD2014 chronology - Part 2: Annual-layer counting (0-31 ka BP), Clim. Past., 12, 769-786, https://doi.org/10.5194/cp-12-769-2016, 2016.

825 Smith, V. C., Costa, A., Aguirre-Díaz, G., Pedrazzi, D., Scifo, A., Plunkett, G., Poret, M., Tournigand, P.-Y., Miles, D., Dee, M. W., McConnell, J. R., Sunyé-Puchol, Dávila Harris, P., Sigl, M., Pilcher, J. R., Chellman, N., and Gutiérrez, E.: The magnitude and impact of the 431 CE Tierra Blanca Joven eruption of Ilopango, El Salvador, P. Natl. Acad. Sci. USA, 117, 26061-26068, https://doi.org/10.1073/pnas.2003008117, 2020.

830 Steig, E. J., Ding, Q. H., White, J. W. C., Kuttel, M., Rupper, S. B., Neumann, T. A., Neff, P. D., Gallant, A. J. E., Mayewski, P. A., Taylor, K. C., Hoffmann, G., Dixon, D. A., Schoenemann, S. W., Markle, B. R., Fudge, T. J., Schneider, D. P., Schauer, A. J., Teel, R. P., Vaughn, B. H., Burgener, L., Williams, J., and Korotkikh, E.: Recent climate and ice-sheet changes in West Antarctica compared with the past 2,000 years, Nat Geosci, 6, 372-375, https://doi.org/10.1038/ngeo1778 2013.

835 Steiger, N. J., Smerdon, J. E., Cook, E. R., and Cook, B. I.: Data Descriptor: A reconstruction of global hydroclimate and dynamical variables over the Common Era, Sci Data, 5, 180086 https://doi.org/10.1038/sdata.2018.86, 2018.

Stevenson, J. A., Millington, S. C., Beckett, F. M., Swindles, G. T., and Thordarson, T.: Big grains go far: understanding the discrepancy between tephrochronology and satellite infrared measurements of volcanic ash, Atmos. Meas. Tech., 8, 20692091, https://doi.org/10.5194/amt-8-2069-2015, 2015.

Stothers, R. B.: Major optical depth perturbations to the stratosphere from volcanic eruptions: Pyrheliometric period, 18811960, J. Geophys. Res., 101(D2), 3901-3920, https://doi.org/10.1029/95JD03237, 1996.

845 Sun, C., Plunkett, G., Liu, J., Zhao, H., Sigl, M., McConnell, J. R., Pilcher, J. R., Vinther, B., Steffensen, J. P., and Hall, V.: Ash from Changbaishan Millennium eruption recorded in Greenland ice: Implications for determining the eruption's timing and impact, Geophys. Res. Lett., 41, 694-701, https://doi.org/10.1002/2013GL058642, 2014. 
https://doi.org/10.5194/cp-2021-63

Preprint. Discussion started: 16 June 2021

(c) Author(s) 2021. CC BY 4.0 License.

\section{(c) (1)}

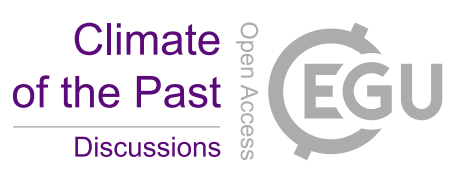

Sun, S. S. and McDonough, W. F.: Chemical and isotopic systematics of oceanic basalts: implications for mantle composition and processes, Geol. Soc London, Special Publications, 42, 313-345, https://doi.org/10.1144/GSL.SP.1989.042.01.19, 1989.

Tardif, R., Hakim, G. J., Perkins, W. A., Horlick, K. A., Erb, M. P., Emile-Geay, J., Anderson, D. M., Steig, E. J., and Noone, D.: Last Millennium Reanalysis with an expanded proxy database and seasonal proxy modeling, Clim. Past, 15, 1251-1273, https://doi.org/10.5194/cp-15-1251-2019, 2019.

855

Tejedor, E., Steiger, N. J., Smerdon, J. E., Serrano-Notivoli, R., and Vuille, M.: Global hydroclimatic response to tropical volcanic eruptions over the last millennium, $\mathrm{P}$ Natl Acad Sci USA, 118, e2019145118, https://doi.org/10.1073/pnas.2019145118, 2021.

860 Tomlinson, E. L., Smith, V. C., Albert, P. G., Aydar, E., Civetta, L., Cioni, R., Çubukçu, E., Gertisser, R., Isaia, R., Menzies, M. A., and Orsi, G.: The major and trace element glass compositions of the productive Mediterranean volcanic sources: tools for correlating distal tephra layers in and around Europe, Quaternary Sci. Rev., 118, 48-66, https://doi.org/10.1016/j.quascirev.2014.10.028, 2015.

865 Toohey, M., Krüger, K., Sigl, M., Stordal, F., and Svensen, H.: Climatic and societal impacts of a volcanic double event at the dawn of the Middle Ages, Clim. Change, 136, 401-412, doi:10.1007/s10584-016-1648-7, 2016.

Toohey, M., Krüger, K., Schmidt, H., Timmreck, C., Sigl, M., Stoffel, M., and Wilson, R.: Disproportionately strong climate forcing from extratropical explosive volcanic eruptions, Nature Geosci., 12, 100-107, https://doi.org/10.1038/s41561-0180286-2, 2019.

Toothill, J., Williams, C. A., Macdonald, R., Turner, S. P., Rogers, N. W., Hawkesworth, C. J., Jerram, D. A., Ottley, C. J., and Tindle, A. G.: A complex petrogenesis for an arc magmatic suite, St Kitts, Lesser Antilles, J. Petrol., 48, 3-42, https://doi.org/10.1093/petrology/eg1052, 2007.

Vinther, B. M., Clausen, H. B., Johnsen, S. J., Rasmussen, S. O., Andersen, K. K., Buchardt, S. L., Dahl-Jensen, D., Seierstad, I. K., Siggaard-Andersen, M.-L., Steffensen, J. P., Svensson, A., Olsen, J., and Heinemeier, J.: A synchronized dating of three Greenland ice cores throughout the Holocene, J. Geophys. Res., 111, D13102, https://doi.org/10.1029/2005JD006921, 2006.

880 Vinther, B. M., Clausen, H. B., Fisher, D. A., Koerner, R. M., Johnsen, S. J., Andersen, K. K., Dahl-Jensen, D., Rasmussen, S. O., Steffensen, J. P., and Svensson, A. M.: Synchronizing ice cores from the Renland and Agassiz ice caps to the Greenland ice core chronology, J. Geophys. Res. - Atmos., 113, D08115, 2008. 
https://doi.org/10.5194/cp-2021-63

Preprint. Discussion started: 16 June 2021

(c) Author(s) 2021. CC BY 4.0 License.

(c) (i)

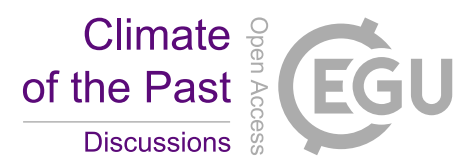

Wastegård, S., Johansson, H., and Pacheco, J. M.: New major element analyses of proximal tephras from the Azores and suggested correlations with cryptotephras in North-West Europe, J. Quaternary Sci., 35, 114-121, https://doi.org/10.1002/jqs.3155, 2020.

Watt, S. F., Pyle, D. M., Naranjo, J. A., Rosqvist, G., Mella, M., Mather, T. A., and Moreno, H.: Holocene tephrochronology of the Hualaihue region (Andean southern volcanic zone, 42 S), southern Chile, Quaternary Int., 246, 324-343, 890 https://doi.org/10.1016/j.quaint.2011.05.029, 2011.

Winski, D. A., Fudge, T. J., Ferris, D. G., Osterberg, E. C., Fegyveresi, J. M., Cole-Dai, J., Thundercloud, Z., Cox, T. S., Kreutz, K. J., Ortman, N., Buizert, C., Epifanio, J., Brook, E. J., Beaudette, R., Severinghaus, J., Sowers, T., Steig, E. J., Kahle, E. C., Jones, T. R., Morris, V., Aydin, M., Nicewonger, M. R., Casey, K. A., Alley, R. B., Waddington, E. D., Iverson, N. A., 895 Dunbar, N. W., Bay, R. C., Souney, J. M., Sigl, M., and McConnell, J. R.: The SP19 chronology for the South Pole Ice Core - Part 1: volcanic matching and annual layer counting, Clim. Past, 15, 1793-1808, https://doi.org/10.5194/cp-15-1793-2019, 2019.

Zhu, F., Emile-Geay, J., Hakim, G. J., King, J., and Anchukaitis, K. J.: Resolving the differences in the simulated and 900 reconstructed temperature response to volcanism, Geophys. Res. Lett., 47, e2019GL086908, https://doi.org/10.1029/2019GL086908, 2020.

Zielinski, G. A.: Stratospheric loading and optical depth estimates of explosive volcanism over the last 2100 years derived from the Greenland Ice Sheet Project 2 ice core, J. Geophys. Res.: Atmos., 100, D10, 20937-20955, 905 https://doi.org/10.1029/95JD01751, 1995.

Zielinski, G. A., Mayewski, P. A., Meeker, L. D., Whitlow, S., Twickler, M. S., Morrison, M., Meese, D. A., Gow, A. J., and Alley, R. B.: Record of volcanism since 7000 B.C. from the GISP2 Greenland ice core and implications for the volcano-climate system, Science, 264, 948-952, https://doi.org/10.1126/science.264.5161.948, 1994. 
https://doi.org/10.5194/cp-2021-63

Preprint. Discussion started: 16 June 2021

(c) Author(s) 2021. CC BY 4.0 License.

Climate

of the Past

Discussions

(c) (i)

Table 1: Volcanic sulfate deposition and duration of above-background sulfate levels for three volcanic events in Greenland ice cores (Sigl et al., 2013, 2015; McConnell et al., 2018, 2020; Clausen et al., 1997; Zielinski, 1995; Toohey \& Sigl, 2017).

\begin{tabular}{|c|c|c|c|c|}
\hline Ice Core & Parameter & Okmok 43 BCE & UE $88 \mathrm{CE}$ & UE 536 CE \\
\hline \multirow[t]{2}{*}{ NEEM-2011-S1 } & $\mathrm{SO}_{4}^{2-}\left(\mathrm{kg} \mathrm{km}^{-2} \mathrm{y}\right)$ & 101 & 83 & 102 \\
\hline & Years of high $\mathrm{SO}_{4}^{2-}$ & 2.0 & 1.9 & 1.7 \\
\hline \multirow[t]{2}{*}{ NGRIP2 } & $\mathrm{SO}_{4}{ }^{2-}\left(\mathrm{kg} \mathrm{km}^{-2} \mathrm{y}\right)$ & 123 & 32 & 83 \\
\hline & Years of high $\mathrm{SO}_{4}^{2-}$ & 2.8 & 0.7 & 2.2 \\
\hline \multirow[t]{2}{*}{ GRIP } & $\mathrm{SO}_{4}^{2-}\left(\mathrm{kg} \mathrm{km}^{-2} \mathrm{y}\right)$ & 135 & 26 & 43 \\
\hline & Years of high $\mathrm{SO}_{4}{ }^{2-}$ & 2.7 & 0.5 & 0.9 \\
\hline \multirow[t]{2}{*}{ Dye 3} & $\mathrm{SO}_{4}^{2-}\left(\mathrm{kg} \mathrm{km}^{-2} \mathrm{y}\right)$ & 108 & 31 & 73 \\
\hline & Years of high $\mathrm{SO}_{4}{ }^{2-}$ & 1.5 & 0.4 & 2.1 \\
\hline GISP2 & $\mathrm{SO}_{4}^{2-}\left(\mathrm{kg} \mathrm{km}^{-2} \mathrm{y}\right)$ & 120 & 29 & no data \\
\hline \multirow[t]{2}{*}{ Greenland $(\mathrm{N}=4)$} & Years of high $\mathrm{SO}_{4}{ }^{2-}$ & 2.3 & 0.9 & 1.7 \\
\hline & Stdev [s.e.m.] & $0.6[0.3]$ & $0.7[0.3]$ & $0.6[0.3]$ \\
\hline \multirow[t]{3}{*}{ Greenland $(\mathrm{N}=5)$} & $\mathrm{SO}_{4}^{2-}\left(\mathrm{kg} \mathrm{km}^{-2} \mathrm{y}\right)$ & 117 & 40 & 75 \\
\hline & Stdev [s.e.m.] & $13[6]$ & $24[11]$ & $25[11]$ \\
\hline & $\begin{array}{l}\text { Stratospheric sulfur } \\
\text { injection }(\mathrm{TgS})\end{array}$ & $39 \pm 11$ & $11 \pm 4$ & $19 \pm 7$ \\
\hline
\end{tabular}


https://doi.org/10.5194/cp-2021-63

Preprint. Discussion started: 16 June 2021

(c) Author(s) 2021. CC BY 4.0 License.

Climate of the Past

Discussions

(c) (i)

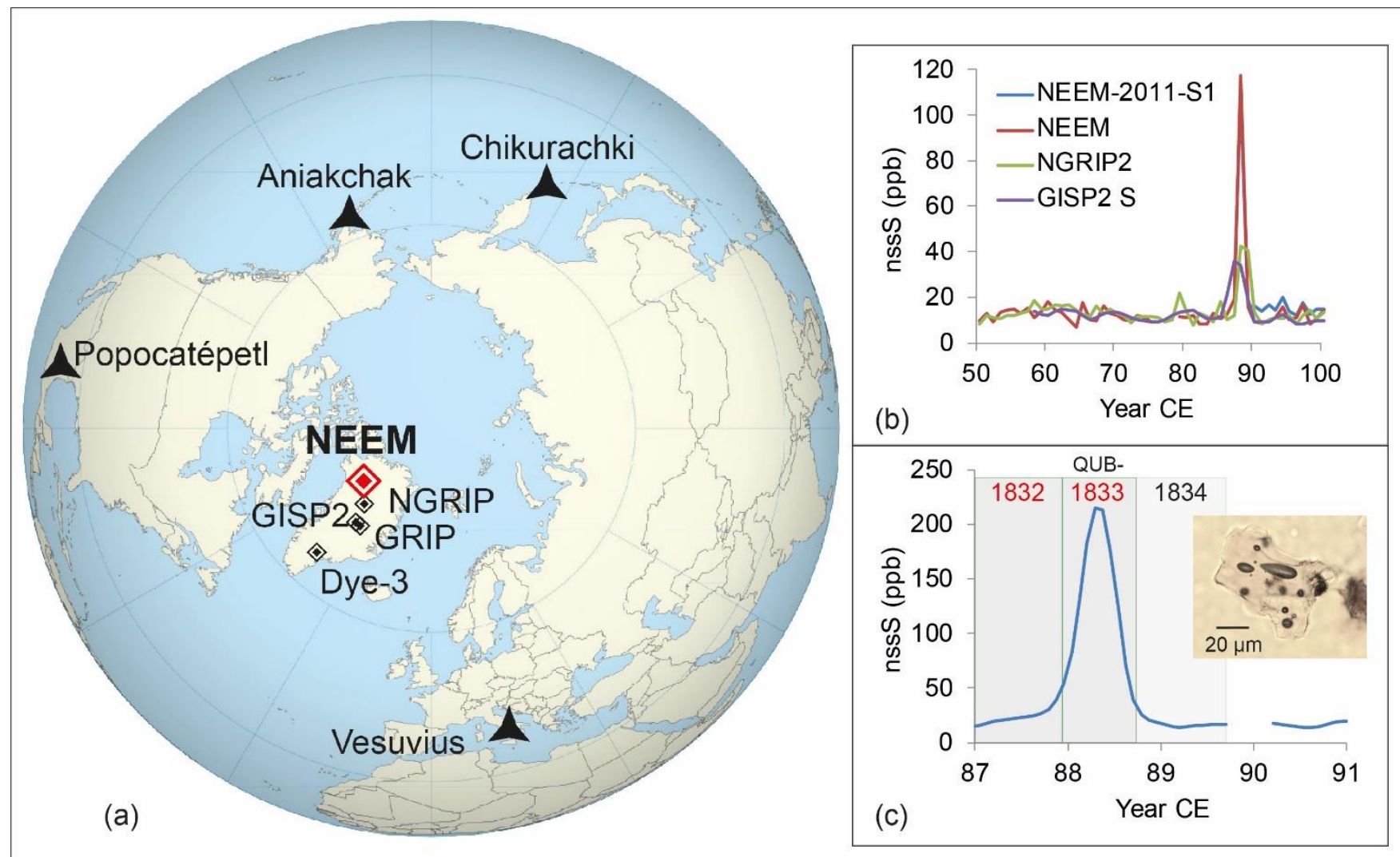

Figure 1. Key sites and ice core records referred to in this paper: a) location of Greenland ice core drill sites and volcanic sources discussed in this paper; b) non-sea salt sulfur (nssS) from four Greenland ice cores showing prominent peak at $88 \mathrm{CE}$; c) detail of nssS peak in the NEEM-2011-S1 ice core, and position of the samples examined in this study (inset shows tephra shard found in sample QUB-1832). 

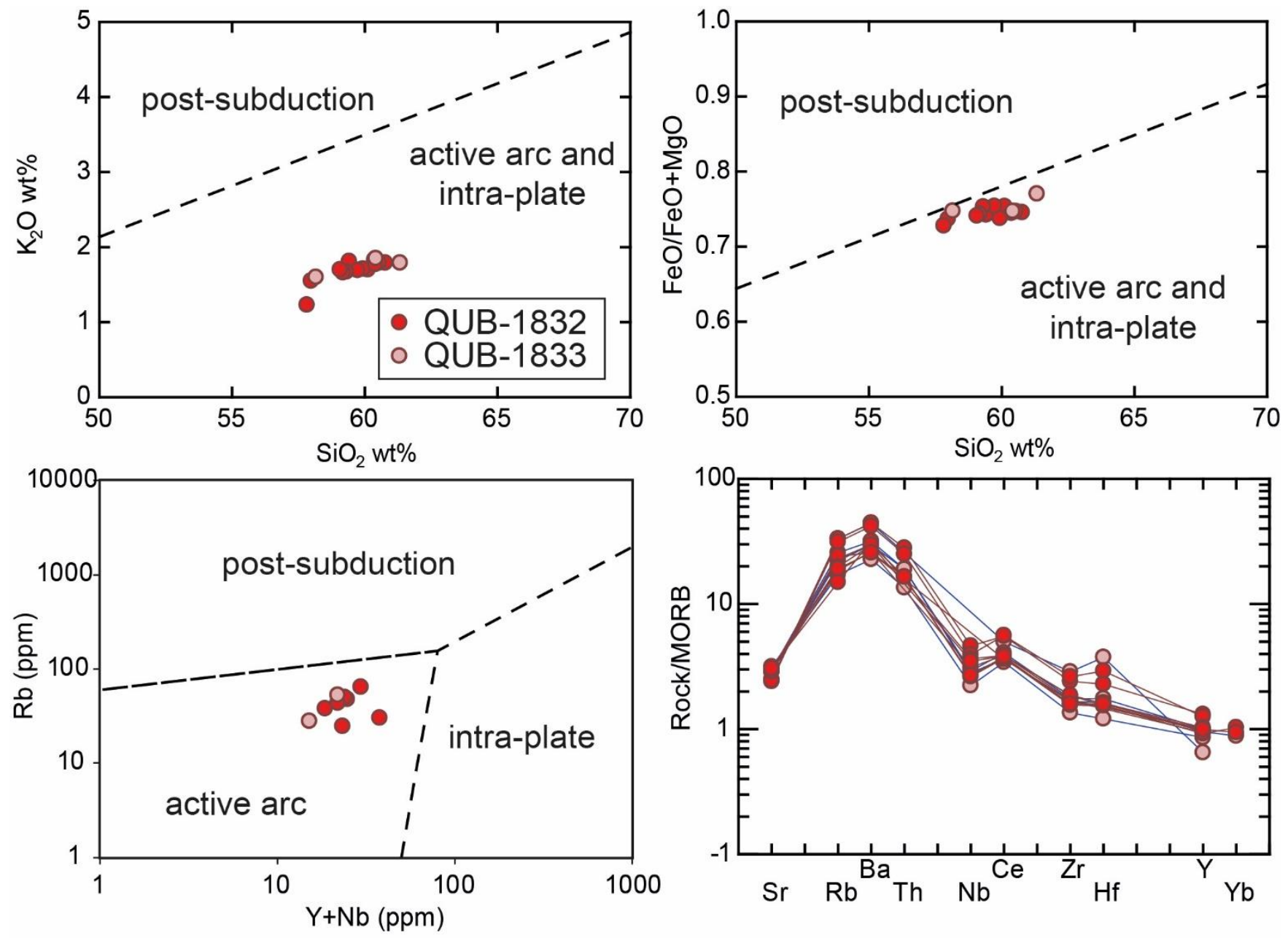

Figure 2. Selected geochemical biplots and spider plot showing compositional similarities of glass shards from samples QUB-1832 and -1833 from NEEM-2011-S1. Plate setting differentiations are based on Tomlinson et al. (2015) and MORB normalized spider diagram follows Pearce (1983). 
https://doi.org/10.5194/cp-2021-63

Preprint. Discussion started: 16 June 2021

(c) Author(s) 2021. CC BY 4.0 License.

(c) (i)
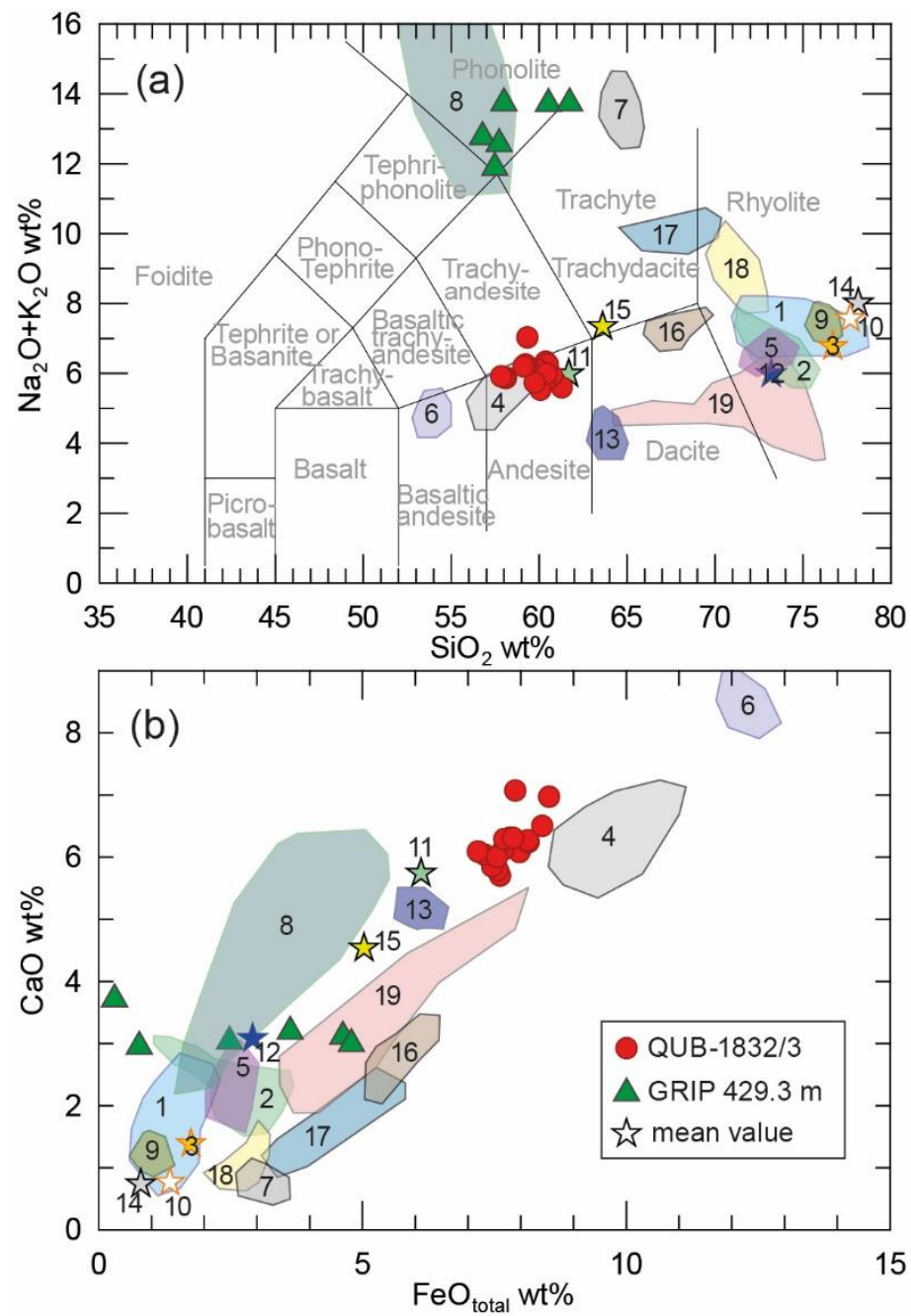

Figure 3. Comparison of QUB-1832/3 glass geochemistry with known VEI 4-6 eruptions in the approximate timeframe. a) Total alkali-silica plot (following Le Bas et al., 1986) and b) FeOtotal $\mathrm{CaO}$ biplot, showing major element geochemical differentiation of QUB1832/3 from known VEI 4 to 6 eruptions in the period 100 BCE to 300 BCE and the GRIP $492.2 \mathrm{~m}$ tephra recorded by Barbante et al. (2013). 1 - Churchill WRAn (Preece et al., 2014); 2 - Ksudach KS 1 (Plunkett et al., 2015); 3 - Taupo (Newnham et al., 1995); 4 - Okmok (McConnell et al., 2020); 5 - Apoyeque Chiltepe (Kutterolf et al., 2008); 6 - Masaya Tuff (Kutterolf et al., 2008); 7 - Furnas C (Wastegård et al., 2020); 8 - Vesuvius (Santacroce et al., 2008); 9 - Shiveluch units 18 and 21 (Ponomareva et al., 2015); 10 935 Glacier Peak A (Foit et al., 2004); 11 - Tacaná Mixcun (ICP analysis; Macías et al., 2000); 12 - Pelée P3 (Martel and Poussineau, 2007; 13 - Cotopaxi KA1 (Garrison et al., 2011); 14 - Merapi (Andreastuti, 1999); 15 - El Misti (Legros 2001) [note: Fe value shown is $\mathrm{Fe}_{2} \mathrm{O}_{3}$ ]; 16 - Katla SILK-Yn (Dugmore et al., 2000); 17 - Snaefellsjökull Sn-1 (Larsen et al., 2001); 18 - Torfajökull Grakolla (Oládóttir et al., 2011); 19 - Askja A-2000/Glen Garry (Barber et al., 2008). 
https://doi.org/10.5194/cp-2021-63

Preprint. Discussion started: 16 June 2021

(c) Author(s) 2021. CC BY 4.0 License.

(c) (i)
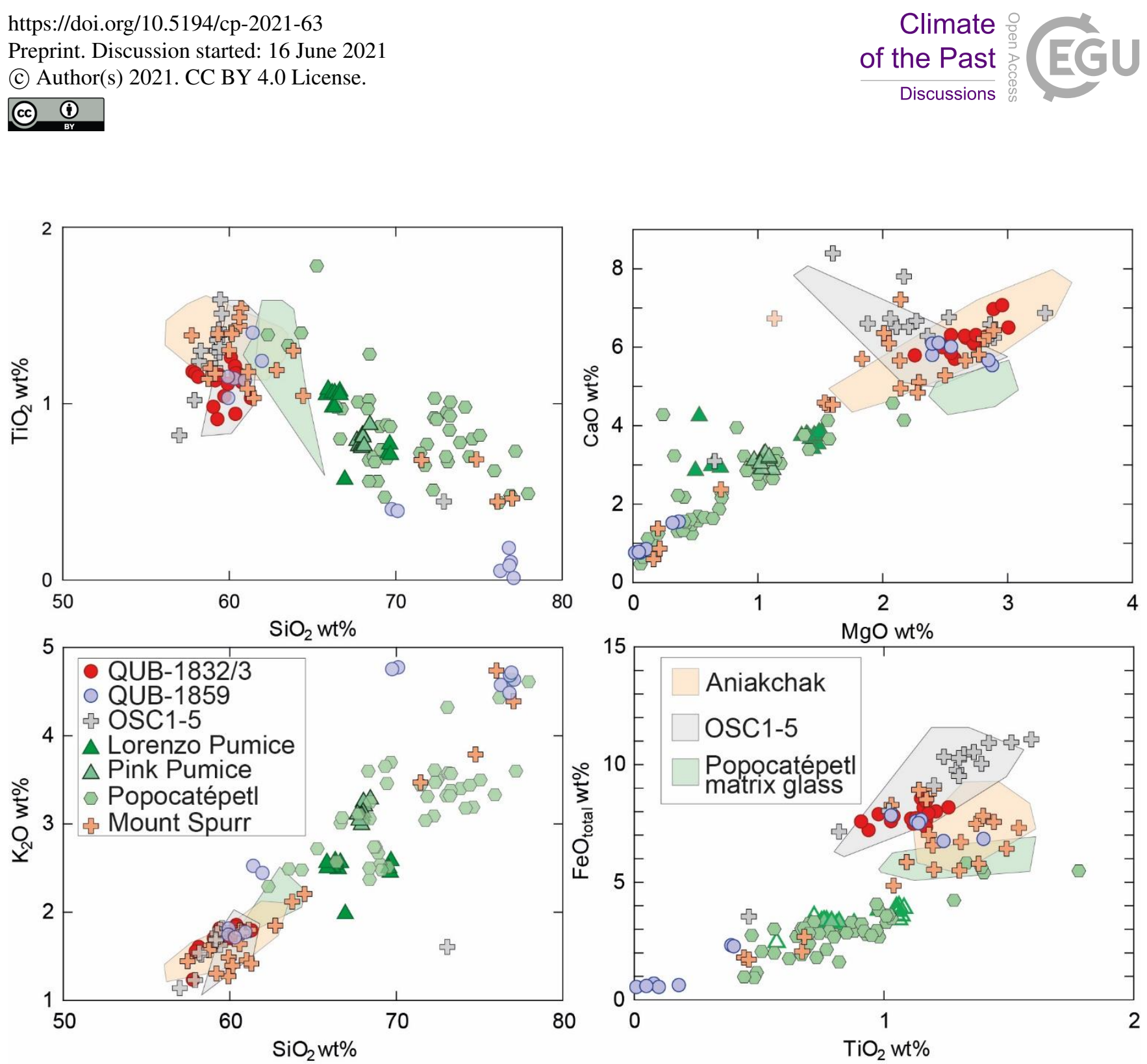

Figure 4. Individual glass shard major element composition of QUB-19832/3 compared with close correlatives. Compositional fields are based on published data: Aniakchak (Kaufman et al., 2012; Davies et al., 2016); OSC 1-5 (Hasegawa et al., 2011); Popocatépetl matrix glass (Siebe et al., 1996). Mount Spurr points represent published mean values (Riehle et al., 1985; Béget et al., 1994). QUB1859 data are from Sigl et al. (2015). 
https://doi.org/10.5194/cp-2021-63

Preprint. Discussion started: 16 June 2021

(c) Author(s) 2021. CC BY 4.0 License.
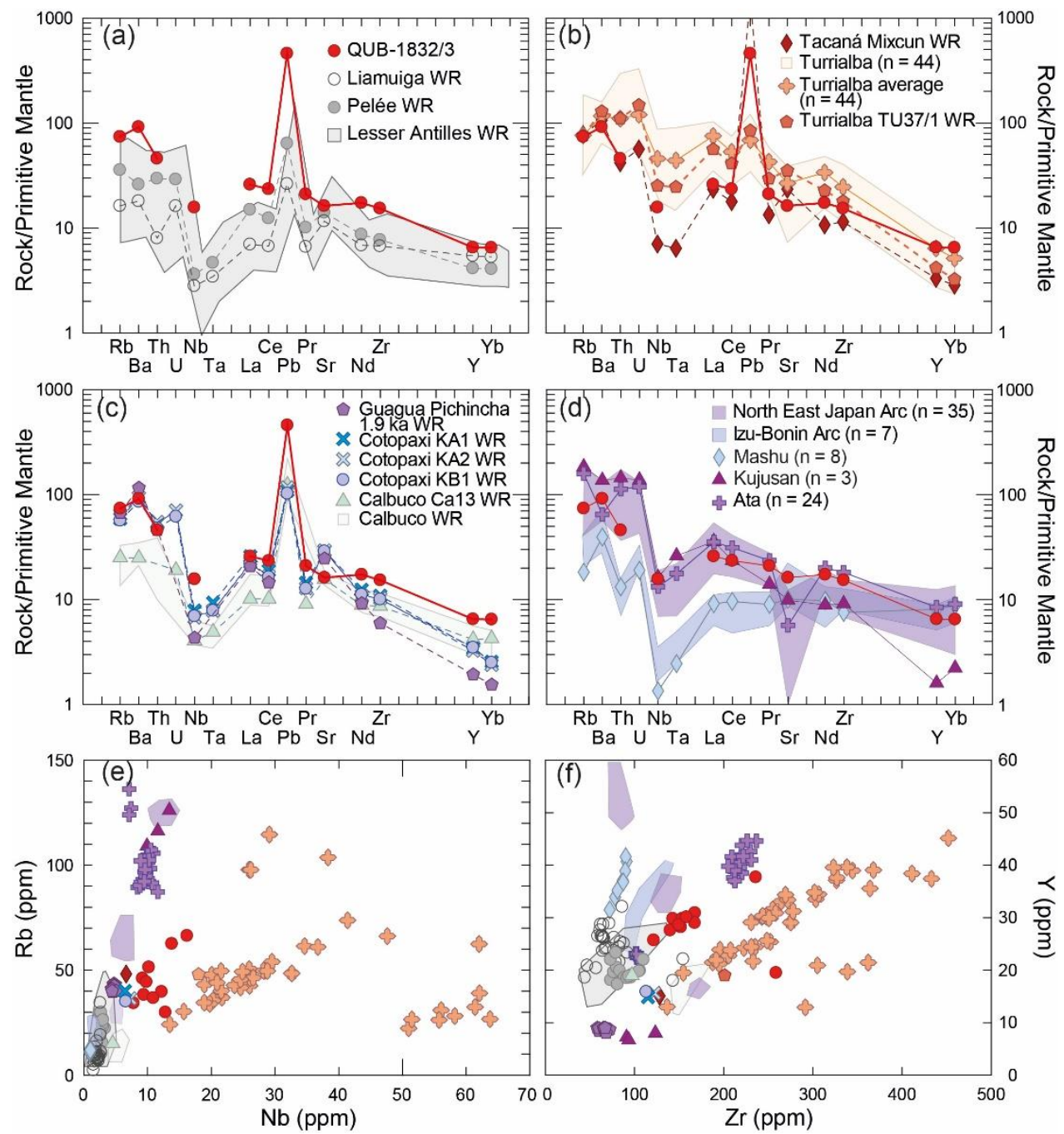

Figure 5. Trace element composition of QUB-1832/3 compared with tephras from known large eruptions between $100 \mathrm{BCE}$ and 300 CE. WR indicates data from whole rock analysis; for averaged and field glass analyses, number of datapoints is given. a-d) Normalized primitive mantle composition (following Sun and McDonough, 1989) of QUB-1832/3 compared with potential source regions/volcanoes: a) Lesser Antilles field (Toothill et al., 2007; Dufrane et al., 2009; Cassidy et al., 2012; Labanieh et al., 2012; Howe et al., 2014, 2015), with average values for Liamuiga (Toothill et al., 2007) and Pelée (Labanieh et al., 2012); b) Japanese volcanic zones after (Albert et al., 2019); c) whole rock composition for the first century CE eruptions of Tacaná (Mixcun Flow Deposit; Mora et al., 2013) and Turrialba (TU37/1; DiPiazza et al., 2015) with glass trace compositional field of more recent Turrialba eruptives (DeVitre et al., 2019); d) averaged whole rock values for the 1st to 2nd century CE eruptions of Guagua Pichincha (Samiengo et al., 2010) and Cotopaxi (Garrison et al., 2011), and the compositional field of Calbuco, including the 8th century CE Ca13 eruption (Watt et al., 2011). e-f) Selected biplots showing variance in selected high field strength elements. 
https://doi.org/10.5194/cp-2021-63

Preprint. Discussion started: 16 June 2021

(c) Author(s) 2021. CC BY 4.0 License.

(c) (i)
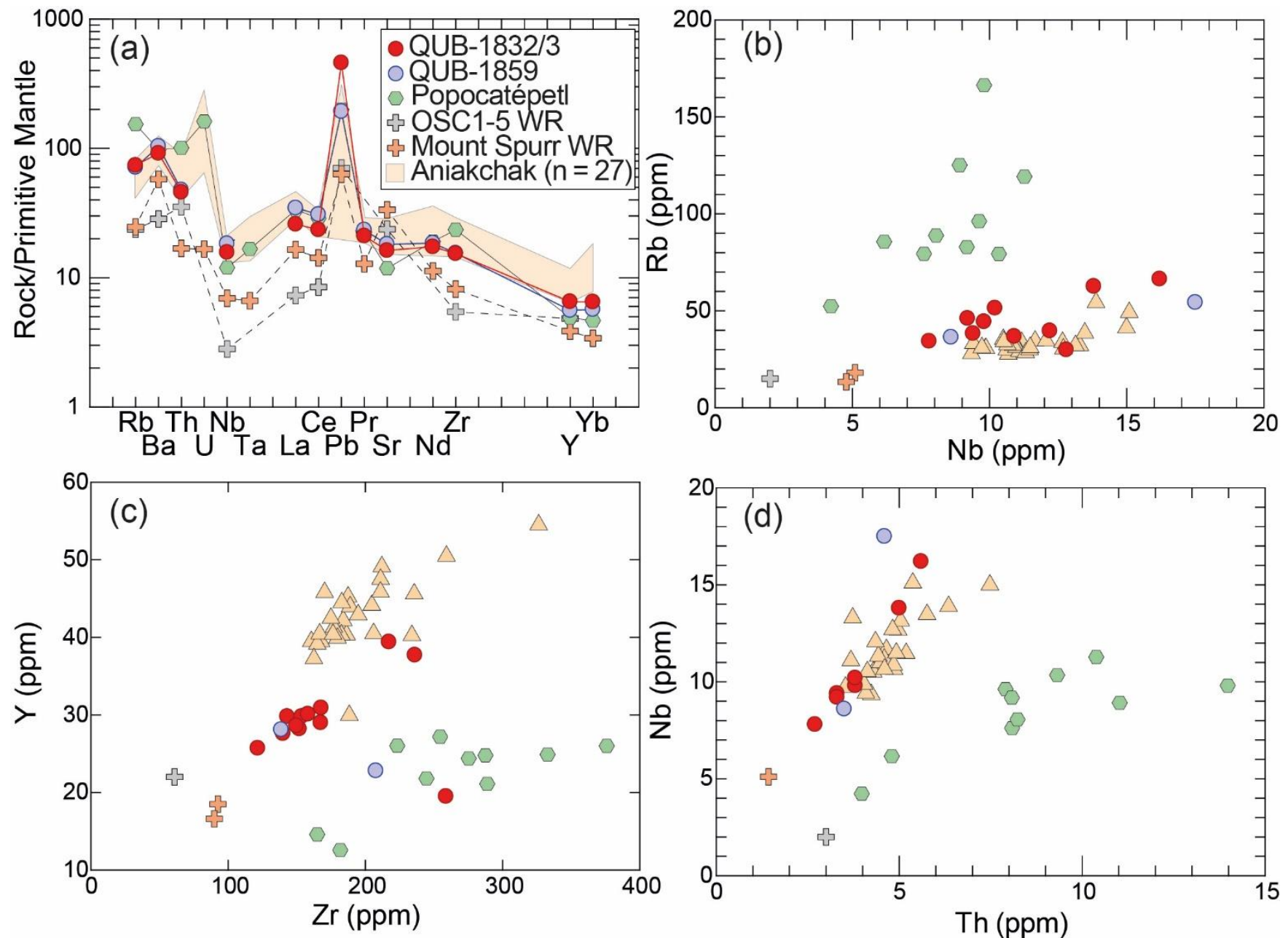

Figure 6. Trace element composition of QUB1832/3 against close correlatives in major element glass composition. WR indicates data

from whole rock analysis. Aniakchak field based on individual glass shard analyses in Kaufman et al. (2012). Mount Spurr data based on George et al. (2003). a) Normalized primitive mantle composition (following Sun and McDonough, 1989); b-d) Selected biplots of High Field Strength Elements (HFSE). 
https://doi.org/10.5194/cp-2021-63

Preprint. Discussion started: 16 June 2021

(c) Author(s) 2021. CC BY 4.0 License.

\section{Climate of the Past \\ Discussions

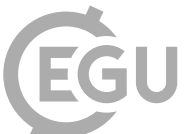

(c) (i)
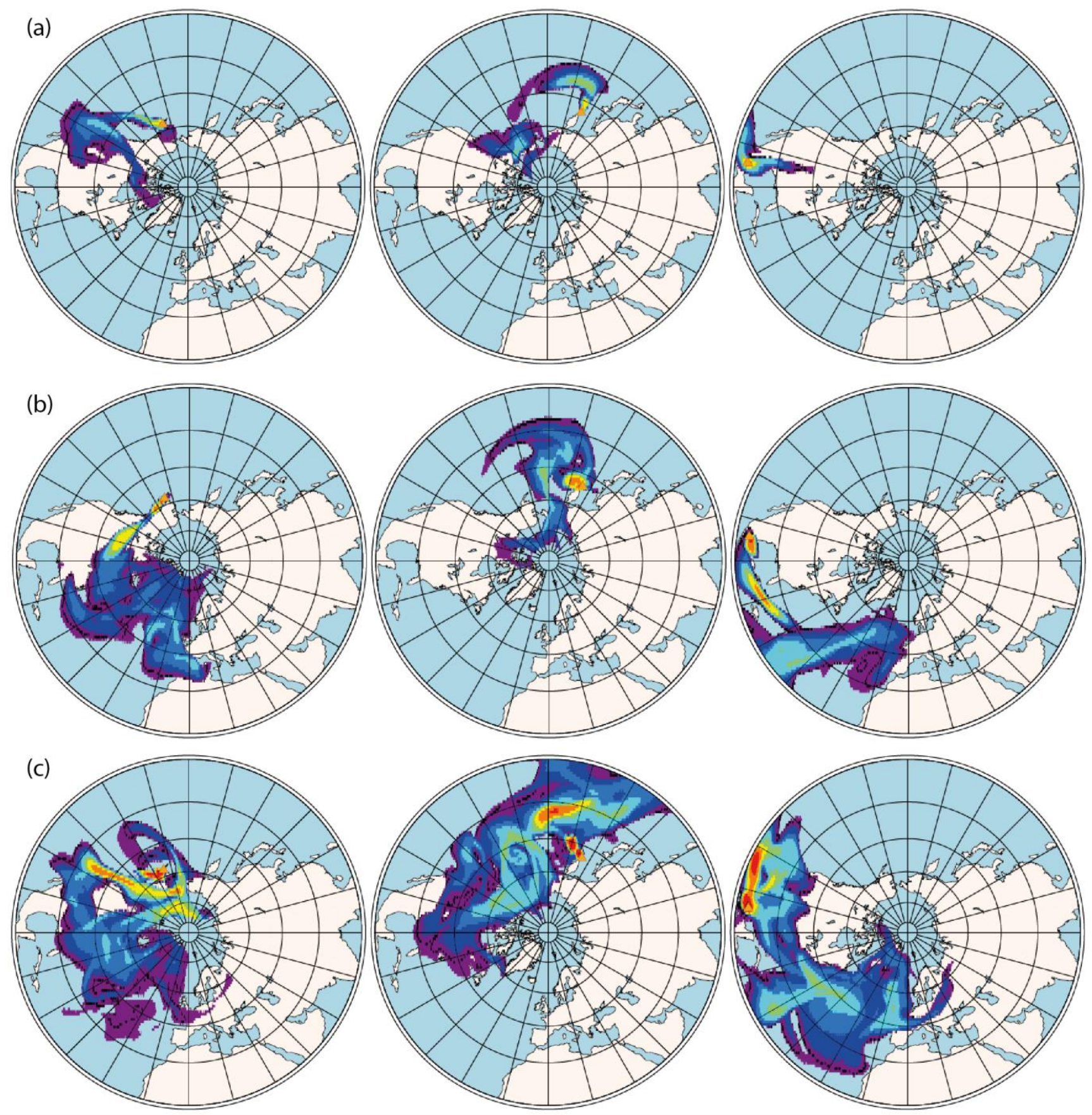

965 Figure 7. Ash3d simulations of ash fallout from Aniakchak (left), Chikurachki (center) and Popocatépetl (right) following randomized start dates between 1950-2010: a) $16 \mathrm{~km}$ high column, eruption duration 9 hours, erupted ash volume $0.3 \mathrm{~km}^{3}$; b) 20 km high column, eruption duration 12 hours, erupted ash volume $0.41 \mathrm{~km}^{3}$; c) $30 \mathrm{~km}$ high column, eruption duration 8 hours, erupted ash volume $1.75 \mathrm{~km}^{3}$. The spectrum denotes deposit thickness (red being thickest). 
https://doi.org/10.5194/cp-2021-63

Preprint. Discussion started: 16 June 2021

(c) Author(s) 2021. CC BY 4.0 License.

(c) (i)
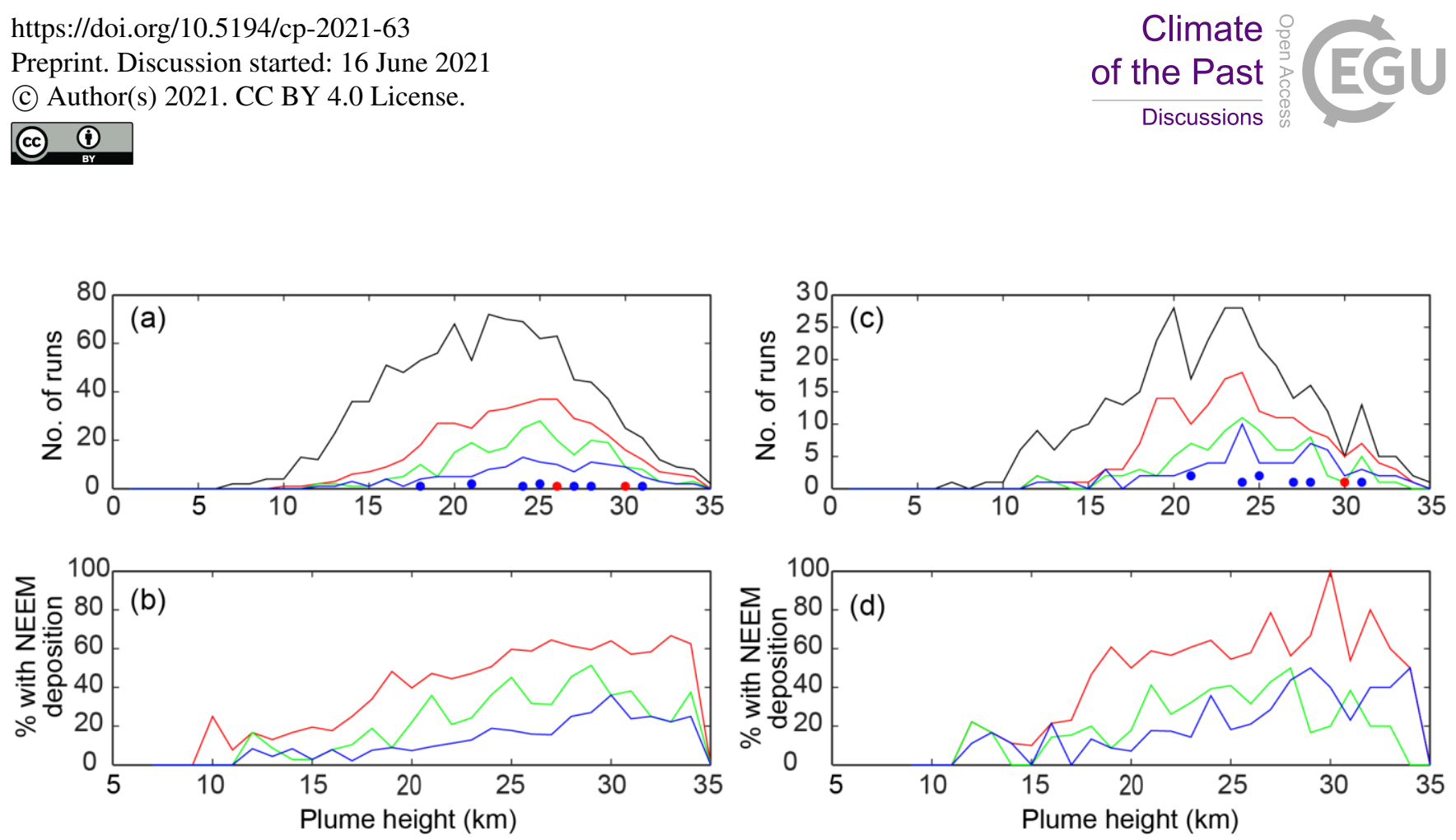

Figure 8. Summary of Ash3d modeling of tephra fallout in Greenland: (a) distribution of total runs (black line) for 1,000 randomized eruption scenarios along with the number of simulations resulting in $31 \mu \mathrm{m}$ ash (colored lines) and $63 \mu \mathrm{m}$ ash (dots) fallout at $\mathrm{NEEM}$ for each hypothetical eruption; (b) the percentage of cases with fallout at NEEM for all months; (c) distribution of plume heights for randomized eruption scenarios during November to February, along with the number of corresponding cases with $63 \mu \mathrm{m}$ fallout at NEEM for each hypothetical eruption (dots); (d) the percentage of simulated cases with fallout at NEEM for in the winter months (November to February). 